\title{
Endocrine disruption of the epigenome: a breast cancer link
}

\author{
Kevin C Knower ${ }^{1, *}$, Sarah Q To ${ }^{1,2,{ }^{*}}$, Yuet-Kin Leung ${ }^{3}$, Shuk-Mei Ho ${ }^{3}$ and Colin D Clyne ${ }^{1,2}$ \\ ${ }^{1}$ Cancer Drug Discovery, MIMR-PHI Institute of Medical Research, PO BOX 5152, Clayton, \\ Victoria 3168, Australia \\ ${ }^{2}$ Department of Molecular Biology and Biochemistry, Monash University, Clayton, Victoria, Australia \\ ${ }^{3}$ Department of Environmental Health, Center for Environmental Genetics, University of Cincinnati College of \\ Medicine, Cincinnati, Ohio, USA \\ *(K C Knower and S Q To contributed equally to this work)
}

Correspondence should be addressed to K C Knower Email kevin.knower@ princehenrys.org

\begin{abstract}
The heritable component of breast cancer accounts for only a small proportion of total incidences. Environmental and lifestyle factors are therefore considered to among the major influencing components increasing breast cancer risk. Endocrine-disrupting chemicals (EDCs) are ubiquitous in the environment. The estrogenic property of EDCs has thus shown many associations between ongoing exposures and the development of endocrine-related diseases, including breast cancer. The environment consists of a heterogenous population of EDCs and despite many identified modes of action, including that of altering the epigenome, drawing definitive correlations regarding breast cancer has been a point of much discussion. In this review, we describe in detail well-characterized EDCs and their actions in the environment, their ability to disrupt mammary gland formation in animal and human experimental models and their associations with exposure and breast cancer risk. We also highlight the susceptibility of early-life exposure to each EDC to mediate epigenetic alterations, and where possible describe how these epigenome changes influence breast cancer risk.
\end{abstract}

\section{Introduction}

Normal growth and function of the mammary glands are dependent on the body's endocrine system. Many factors that influence breast cancer risk are therefore endocrine-associated processes, such as age at menopause, age at menarche, parity and a women's age at her first pregnancy. The significance and capacity of environmental and exogenous components, such as endocrinedisrupting chemicals (EDCs), to alter endocrine processes have resulted in a greater awareness of these and breast cancer risk. An EDC is defined by the US Environmental Protection Agency as 'an exogenous agent that interferes with synthesis, secretion, transport, metabolism, binding action, or elimination of natural blood-borne hormones that are present in the body and are responsible for homeostasis, reproduction, and developmental process'. The sources of EDCs are diverse as too are their structure and action, making prediction of their endocrinedisrupting properties a challenge. Further to this, EDCs are also a highly heterogenous set of compounds ranging from synthetic chemicals used in plastics, pesticides and pharmaceutical agents to natural chemicals found in human and animal food such as phytoestrogens.

EDCs have been shown to alter mammary development and present adverse lifelong risks in both mouse

\footnotetext{
Published by Bioscientifica Ltd.

This paper is one of three papers that form part of a thematic review section on Endocrine Disruptors and Cancer. The guesteditor for this section was Gail Risbridger $2: 17: 29 \mathrm{PM}$

Monash University، Australia 
and human models (reviewed in Macon \& Fenton (2013)). Originally thought to exert actions primarily through nuclear hormone receptors, such as estrogen (ERs) and progesterone receptors (PRs), research now clearly demonstrates that the mechanisms of EDCs are much broader than originally recognized. Of prominence is the growing relationship identified between EDCs altering the epigenomic landscape in cancers, including in the breast, and common diseases like cardiovascular, pulmonary or neurodegenerative disorders to name a few (Irigaray et al. 2007, Mathers et al. 2010). In such instances, early-life epigenetic programming and also those encountered during adult life are large contributing factors to overall progression of disease states (Fig. 1). Identification of epigenetic markers influenced by environmental compounds will therefore provide a potential means of early detection, prognostic value and functional information of the compound itself. This review discusses and focuses on EDCs capable of altering the epigenome, specifically those that affect endocrine-responsive organs such as the breast.

\section{Alterations in the epigenomic landscape}

The rapidly developing field of epigenetics is an exciting research area in cancer biology. The reversible nature of epigenetic changes makes it an attractive target for novel therapeutic development. Epigenetics describes a range of DNA and histone modifications that influence levels of gene expression without modifications to the underlying coding sequence (Goldberg et al. 2007). Such modifications include DNA methylation, histone modifications and non-coding RNAs (ncRNAs), and involve a tightly regulated network of modifying enzymes. These processes work cooperatively to facilitate gene expression control, $\mathrm{X}$ chromosome inactivation and genomic imprinting. The organization of DNA into chromatin structures around histones is the basis for dynamic changes that promote or suppress gene expression. Loosely packed chromatin allows for access of local transcriptional machinery for gene expression to proceed; however, tightly packed chromatin represents transcriptional repression (Li et al. 2007). DNA methylation and histone modifications work in tandem to determine the open or closed state of the epigenome.

DNA methylation underlies epigenetic regulation, with an inverse relationship generally observed between promoter methylation levels and gene expression. DNA methylation occurs at $\mathrm{CpG}$ sites, cytosine residues immediately adjacent to $5^{\prime}$ of guanine. CpG sites occur in clusters known as CpG islands (Ooi et al. 2009), and

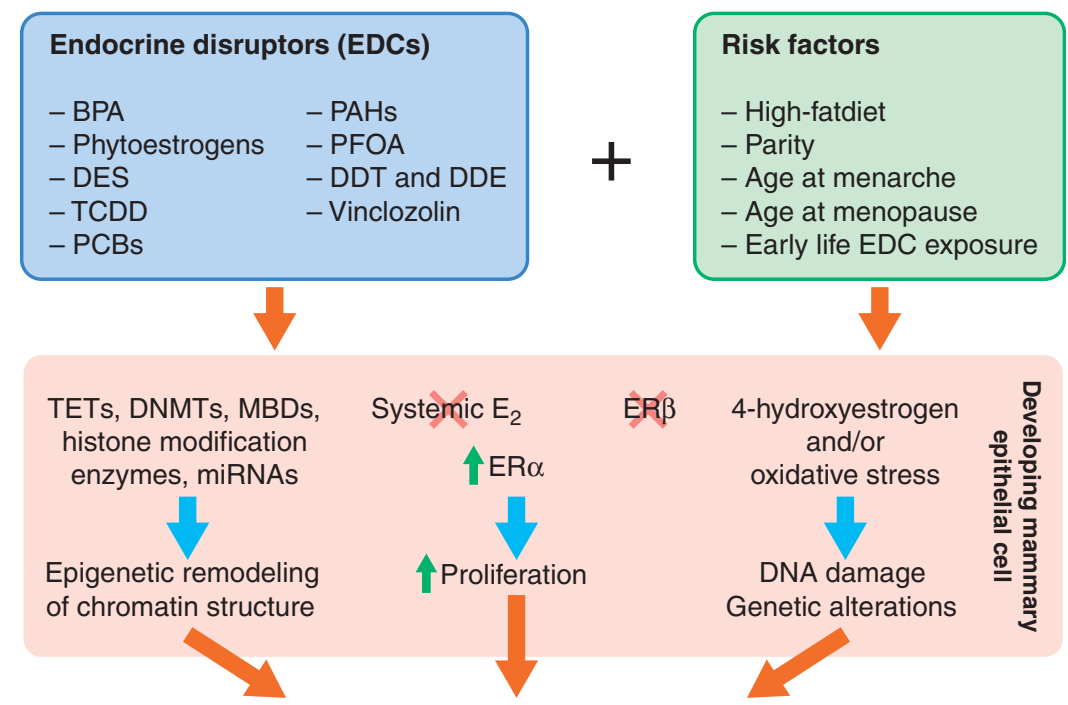

Increased breast cancer risk?

\section{Figure 1}

Endocrine disruptors and risk factors mediate epigenome changes increasing breast cancer risk. EDC may prolong puberty and increase mammary epithelial cell proliferation allowing a longer duration or increased rate of epigenetic remodeling of the developing mammary gland leading to destabilization of chromatin integrity, mispackaging of genes in active/inactive domains and aberrant expression of genes in key regulatory pathways. The susceptibility of the action of EDCs is compounded by http://erc.endocrinology-journals.org DOI: 10.1530/ERC-13-0513
(C) 2014 Society for Endocrinology Printed in Great Britain associated risk factors such as a high-fat diet. BPA, bisphenol A; DES diethylstilbestrol; TCDD, 2,3,7,8-tetrachloridibenzo-p-dioxin; PCBs, polychlorinated biphenyls; PAHs, polycyclic aromatic hydrocarbons; PFOA, perfluorooctanoic acid; DDT, dichlorodiphenyltrichloroethane; DDE, 1,1-dichloro-2,2-bis( $p$-chlorophenyl)ethylene; TETs, Ten-Eleven Translocation proteins; DNMTs, DNA methyltransferases; MBDs, methyl-CpG-binding domain proteins; ER, estrogen receptor 
these are found in $\sim 50 \%$ of human gene promoters (You \& Jones 2012). Hypermethylation of CpG sites within a promoter region leads to recruitment of histone-modifying enzymes to the local chromatin area to compact its structure and therefore prevent access of transcriptional machinery (Nan et al. 1998). Methylation of even a single CpG site may influence gene transcription, as it may interfere with the binding of transcription factors to their response elements (Demura \& Bulun 2008). CpG methylation in non-promoter regions such as enhancers and introns can also alter gene expression levels (van Roon et al. 2011, Sandovici et al. 2011). DNA methylation is catalyzed by three methyltransferase enzymes: DNMT1, which is mainly responsible for the maintenance of existing DNA methylation patterns, and DNMT3a and DNMT3b, which not only establish de novo methylation during development but also maintain methylation patterns to a lesser degree (Hermann et al. 2004).

Mechanisms of DNA demethylation have more recently been uncovered, with the present model outlining both passive and active methods of demethylating CpG sites. Passive demethylation occurs when an error of methylation maintenance during replication leads to a loss of methylation on the daughter strand (Bhutani et al. 2011). Conversely, active demethylation is the result of a cascade of enzyme actions. Ten-Eleven Translocation (TET) proteins are initially responsible for hydroxylation of methylated cytosines (Tahiliani et al. 2009), following which activation-induced cytidine deaminase enzymes deaminate the DNA (Morgan et al. 2004). Alternatively, it has also been suggested that hydroxy-methylated DNA is not recognized by maintenance DNMTs, and therefore hydroxylation by TET proteins may lead to a loss of methylation patterns through subsequent cell cycles (He et al. 2011).

DNA methylation and histone modifications are intrinsically linked, working cooperatively to regulate gene expression. The recruitment of DNMTs to CpG sites may be mediated by histone modifications (Lindroth et al. 2004, Vire et al. 2006), conversely methylated CpG sites facilitate the recruitment of methyl-binding proteins to the genomic region (Boyes \& Bird 1992, Bogdanovic \& Veenstra 2009), which in turn recruit histone deacetylase enzymes (HDACs; Nan et al. 1998). Deacetylation of lysine residues on histone tails results in compaction of local chromatin structure to prevent access of transcriptional machinery and therefore repress gene transcription. To date, 18 HDAC family members have been identified and separated into class I and class II. HDACs are able to deacetylate not only histone tails but also non-histone proteins including transcription factors (Choudhary et al. 2009, Reichert et al. 2012). HDAC proteins work cooperatively with histone acetyltransferases to maintain correct histone acetylation patterns in normal cells. Histone acetyltransferases catalyze the transfer of acetyl groups from acetyl CoA to lysine residues on histone tails, resulting in an overall net reduction to chromatin compaction (Furdas et al. 2012).

Additional histone modifications are also critical to dictating chromatin signatures. Lysine residues may be mono-, di- or trimethylated, although this is thought to have a less direct effect on chromatin dynamics due to the nil effect this has on overall histone charge (Zentner \& Henikoff 2013). Mono- or dimethylation can also occur on arginine residues, although the effect this has on nucleosomes is unclear (Bedford \& Clarke 2009). Serine residues may also be phosphorylated to alter the affinity of histone-binding proteins (Hirota et al. 2005). Other histone modifications that have been characterized to date include sumoylation, ubiquitination, ADP ribosylation (Petesch \& Lis 2012) and glycosylation (Sakabe et al. 2010), although it is not well understood how these processes affect nucleosomes dynamics.

Small ncRNAs are also a critical component of the cell's epigenetic regulatory mechanisms. ncRNAs are broadly divided into long and short forms, with long ncRNAs generally categorized as those over 200 nucleotides in length. Long ncRNAs can be derived from gene regulatory regions, intragenic regions or mitochondrial DNA (Khalil et al. 2009, Hung et al. 2011, Rackham et al. 2011). They primarily act on the local genomic region from which they were derived by attracting transcription factors or other epigenetic modifying enzymes to the area. They may also serve as precursors of short ncRNAs (Wapinski \& Chang 2011). Micro RNA (miRNA), endogenous siRNA and PIWIinteracting miRNA (piRNA) are the primary types of small ncRNAs found in mammalian systems (Lagos-Quintana et al. 2001, Kim 2006, Okamura et al. 2008). While they differ in their genomic origin, post-translational processing and final structure, all function to post-transcriptionally repress expression of not only their target genes but also other ncRNAs (Qureshi \& Mehler 2012).

\section{Endocrine disruption of the breast creates parallels with the epigenome}

In the following sections, we describe in detail some wellcharacterized EDCs and their actions in the environment, ability to disrupt mammary gland formation in animal and human experimental models, and their associations with

Published by Bioscientifica Ltd. 
exposure and breast cancer risk. We also highlight the susceptibility to epigenetic alterations induced by earlylife exposure to each EDC and where possible describe how these epigenome changes influence the risk of breast cancer. Environmental epigenetics provides direct molecular mechanisms for factors or toxicants to influence the genetic cascade of events involved in development. Critical windows of susceptibility exist where these factors modify and affect important stages of development. Generally, these critical windows are early in development when the developing organ systems are sensitive to alterations in the epigenome. Modification of the epigenome may continue throughout development, subsequently affecting the adult transcriptome and making tissues, such as the breast, susceptible to developing disease.

Importantly in mammals, exposure of gestating females to environmental factors or toxicants during the period of gonadal sex determination can alter epigenetic transgenerational inheritance. The epigenetic reprogramming and imprinting of germ cells can thus allow transgenerational transmission of adult-onset disease phenotypes. While somatic cells play critical roles in the physiology and disease states of individuals, they are not capable of transmitting information between generations. However, early-life epigenetic alterations caused by the environment may nonetheless alter somatic epigenetic stability function throughout life. The findings are summarized in Fig. 1 and Table 1.

\section{Bisphenol A}

Bisphenol A (BPA) is a commercial chemical with a high production volume that is commonly used in the manufacture of a wide variety of consumer goods. These include plastics for bottles and containers, epoxy resins that line metal food and drink cans, dental sealants, water pipe linings and thermal paper production. Through high heat, physical manipulation or repeated use, BPA may leach from these products and unintentionally expose consumers. Oral consumption is the primary method of BPA exposure in humans, with many unknowingly ingesting contaminated food and drink. It is estimated that up to $95 \%$ of the population have detectable concentrations of BPA in their bodies (Calafat et al. 2005). BPA is metabolized to its glucuronidated-conjugate, and has a short half-life of $\sim 5 \mathrm{~h}$ in adults (Volkel et al. 2002). However, in rodents at least, continued exposure results in consistently elevated serum levels of BPA (Sieli et al. 2011). The subject of the correlation between elevated levels of BPA in humans and increased breast cancer risk is highly topical, with no definitive studies showing an association. However, in the following sections, we discuss a number of in vitro and animal studies where BPA alters mammary development and epigenetic processes.

BPA acts as an estrogen mimetic and can interact with the ligand-binding domain of ER $\alpha$ (Sengupta et al. 2013), increasing cellular proliferation, potentially via reducing the rate of apoptosis (Mlynarcikova et al. 2013), and inducing a gene expression profile that clusters with poor breast cancer prognosis (Katchy et al. 2014). BPA also interacts with the orphan nuclear receptor, estrogen-related receptor $\gamma$ (ERR $\gamma$; Takayanagi et al. 2006), and may also signal via the G-protein-coupled receptor GPER/GPR30 (Pupo et al. 2012). Rats and mice which are exposed prenatally to BPA show accelerated growth of the mammary gland coupled with hyperplastic epithelial ducts, more rapid development of mature structures and increased proliferation of stromal cells at an earlier age (Markey et al. 2001, Munoz-de-Toro et al. 2005, Moral et al. 2008, Vandenberg et al. 2008, Soto et al. 2013). Complementary studies have explored the effect of neonatal and early-life exposure to BPA on mammary gland physiology, through administration of BPA via the water supply or oral gavage (Ayyanan et al. 2011, Lamartiniere et al. 2011, Soto et al. 2013). This also resulted in accelerated mammary gland growth in rats and demonstrated the effects of metabolizing and accumulating BPA rather than exposure from maternal serum, where the circulating levels were not determined (Lamartiniere et al. 2011). Rhesus monkeys have also been studied to simulate levels of BPA exposure more physiologically relevant to humans, with similar results being obtained (Tharp et al. 2012). These early alterations in the mammary gland increase susceptibility of animals to 7,12dimethylbenz[ $\alpha]$ anthracene (DMBA)-induced mammary carcinogenesis through at least two mechanisms: molecular alteration of fetal glands without associated morphological changes and direct promotion of estrogen-dependent tumor cell growth, indicating that chronic BPA exposure may accentuate later-life risk of breast cancer development (Durando et al. 2007, Weber Lozada \& Keri 2011).

A number of epigenetic alterations may explain the increased mammary gland proliferation and susceptibility to carcinogenesis observed in animal models. Several small studies have identified specific gene targets that are epigenetically altered in response to BPA that may increase breast epithelial proliferation and tumor development. Treatment of primary human breast epithelial cells with BPA increased DNA methylation levels in the promoter region of the gene encoding lysosomal-associated membrane protein $3, L A M P 3$, and associated decreases in

Published by Bioscientifica Ltd. 
mRNA expression were detected (Weng et al. 2010). Investigation of a panel of clinical breast cancer samples found this increase in DNA methylation to be a characteristic of ER-positive tumors (Weng et al. 2010).
Furthermore, in vitro treatment of MCF-7 ER-positive breast cancer cell lines with BPA resulted in increased expression of $E Z H 2$, a histone methyltransferase enzyme, which has been previously implicated in breast

Table 1 Summary of the epigenetic effects mediated by EDCs in breast cancer

\begin{tabular}{|c|c|}
\hline Endocrine disruptor & Route of exposure \\
\hline Bisphenol A (BPA) & $\begin{array}{l}\text { Plastics, dental } \\
\text { sealants, epoxy } \\
\text { resins, thermal } \\
\text { paper }\end{array}$ \\
\hline Phytoestrogens & $\begin{array}{l}\text { Plant-derived } \\
\text { xenoestrogens } \\
\text { (e.g. soy, tomatoes } \\
\text { and red wine) }\end{array}$ \\
\hline $\begin{array}{l}\text { Diethylstilbestrol } \\
\text { (DES) }\end{array}$ & $\begin{array}{l}\text { Prescribed drug } \\
\text { (discontinued } \\
\text { 1970s) }\end{array}$ \\
\hline $\begin{array}{l}\text { 2,3,7,8-tetrachloridi- } \\
\text { benzo-p-dioxin } \\
\text { (TCDD) }\end{array}$ & $\begin{array}{l}\text { Combustion and } \\
\text { manufacture of } \\
\text { chemicals }\end{array}$ \\
\hline $\begin{array}{l}\text { Polychlorinated } \\
\text { biphenyls (PCBs) }\end{array}$ & $\begin{array}{l}\text { Coolants and heat- } \\
\text { transfer agents }\end{array}$ \\
\hline
\end{tabular}

\section{Breast epigenetic effect \\ Altered methylation of $\angle A M P 3, B R C A 1$, CCNA1, CDNK2A, THBS1, TNFRSF10C and TNFRSF10D \\ Upregulation of $E Z H 2$ \\ Unique miRNA signature \\ Demethylation of $B R C A 1, B R C A 2$ GSTP1, RARB2, CCND2 \\ Repression of DNMT activity \\ Increase in $\mathrm{H} 3$ trimethylation by upregulation of EZH2 expression}

Hypermethylation of BRCA1 prostate, pancreas and
ovaries

Methylation pattern of $\operatorname{Hox}$ genes, Fos and Nsbp1 different in mouse uterus and endometrium

Dnmt1 expression increased in mouse uterus

Transgenerational effects on sperm methylome

Methylation-induced silencing of $p 53$ and p16INK4a in keratonites Increased DNMT activity in mouse embryos

Increased abundance of SAM and $D N M T$, leading to increased methylation in rat liver cells

H4K16Ac post-translational histone modifications reduced

Forms DNA adducts near methylation sites in breast epithelium and breast milk

Alters DNA methylation and histone modification patterns
Perfluorooctanoic
acid (PFOA)
Chemical in surfactants, waterproofing insulating agents and dental products
Insecticides
Distinct miRNA signature in MCF-7 cells
Pesticide
Inverse correlation between in utero exposure and cord blood methylation

GSTP hypermethylated in normal liver cells, leukemia, prostate and liver cancer cells

Reduced expression of Dnmt1 in rat hypothalamus

Germ line epigenetic alterations

\section{References \\ Doherty et al. (2010), Weng et al. (2010), Doshi et al. (2011), Qin et al. (2012), Tilghman et al. (2012) and Kundakovic et al. (2013)}

King-Batoon et al. (2008), Li et al. (2009), Qin et al. (2009), Paluszczak et al. (2010) and Bosviel et al. (2012)

Li et al. (2003), Tang et al. (2008), Bromer et al. (2009), Sato et al. (2009) and Doherty et al. (2010)

Ray \& Swanson (2004), Wu et al. (2004), Papoutsis et al. (2010) and Manikkam et al. (2012)

Fraga et al. (2005) and

Li et al. (1996), GorlewskaRoberts et al. (2002), Thompson et al. (2002), Bradley et al. (2007) and Sadikovic et al. (2007, 2008)

Zhong et al. (2002), Nakayama et al. (2004), GuerreroPreston et al. (2010), Karius et al. (2011) and Tian et al. (2012)

\section{Shutoh et al. (2009) and Tilghman et al. (2012)}

Anway et al. (2006) Desaulniers et al. (2009)

alterations

http://erc.endocrinology-journals.org DOI: 10.1530/ERC-13-0513
(C) 2014 Society for Endocrinology Printed in Great Britain 
tumorigenesis. This resulted in an increase in histone $\mathrm{H} 3$ trimethylation levels, epigenetically altering the expression levels of many genes. These results translated to an in vitro model, as increased EZH2 activity and $\mathrm{H} 3$ trimethylation were also detected in the mammary glands of mice exposed to BPA in utero (Doherty et al. 2010).

Spheres of human mammary epithelial cells increased in both size and proliferation in response to BPA treatment and also showed genetic signs of senescence. Spheres treated with BPA showed increased methylation levels of key genes associated with tumor development, namely BRCA1, CCNA1, CDKN2A, THBS1, TNFRSF1OC and TNFRSF10D, indicating that BPA alters the epigenome in a manner that promotes proliferation, senescence and tumor development (Qin et al. 2012). Additional cell line studies have demonstrated aberrant methylation of the genome resulting in upregulated DNA repair genes and downregulated pro-apoptotic genes (Fernandez et al. 2012), and a unique miRNA signature in BPA-treated cells distinct from miRNAs induced by estradiol (Tilghman et al. 2012).

Taken together, these studies to date provide clear evidence for an epigenetic component to the increased proliferation of the mammary gland and increased susceptibility to tumor development well established in animal models of BPA exposure. While a number of epigenetic targets have been implicated, the mechanisms behind BPA-induced epigenetic changes in the breast are poorly defined at present. BPA is known to increase the transcript level and activity of all three DNA methyltransferases in the brain, prostate and testes (Doshi et al. 2011, Tang et al. 2012b, Kundakovic et al. 2013), and establishing whether this occurs in the breast is important for understanding the mechanisms behind aberrant methylation patterns that have been observed.

\section{Modification of EDC susceptibility by lifestyle elements such as a high-fat diet: modeling the effects of BPA}

Women who immigrate from countries with low incidences of breast cancer risk to those with high incidences rapidly acquire a higher breast cancer risk within the first generation and the breast cancer incidences of their daughters and grand-daughters continue to increase to levels similar to those of residents of their new homelands (Pineda et al. 2001). This epidemiological observation can in part be explained by a shift of their diets from low to high fat content (a typical Western diet has over $35 \%$ fat (McKeigue et al. 1985)). Pregnancy is a critical window for developmental reprogramming of cancer (Walker \& Ho 2012) in response to exposure to various environmental pollutants such as BPA (see above section for discussion). Since in the United States, BPA is one of the most widespread EDCs, detected in over 95\% of the population (Calafat et al. 2008), we asked the previously unexplored question of whether a high-fat diet can modify the mammary glands' susceptibility to BPA via epigenetic modifications, and whether these findings were consistent with previous studies demonstrating the combined effects of maternal high-fat diet and other EDCs on subsequent mammary cancer risks (Walker 1990, Luijten et al. 2004, Davis et al. 2013).

Sprague-Dawley rat dams were fed with various doses of BPA-supplemented high-fat butter diet (HFB) $(2.5-2500 \mu \mathrm{g} / \mathrm{kg}$ body weight) during acclimation and gestation periods (Leung and Ho, unpublished data). In utero exposure of $\mathrm{HFB}+\mathrm{BPA}$ diets did not alter i) daughter's body weight and food consumption, ii) the onset of puberty measured by time of vaginal opening, nor iii) levels of estradiol and progesterone of day-21 daughters compared with a low-fat-BPA diet. However, $\mathrm{HFB}+\mathrm{a}$ low dose of BPA ( $25 \mu \mathrm{g} / \mathrm{kg}$ body weight) showed synergistic effects and caused i) a doubling of terminal end buds (TEBs) in postnatal day-21 mammary glands (these are presumed targets of carcinogenesis and this result was consistent with high-fat diets alone increasing the TEB numbers (Hilakivi-Clarke et al. 1998b)), ii) ER $\alpha$ associated cell proliferation in the epithelial cells of these TEBs (proliferating epithelial cells are known to have low numbers of ER $\alpha$-positive cells (Clarke et al. 1997), iii) a significant loss of $5^{\prime}$ hydroxymethylation of cytosine $(\mathrm{hmC})$ and $5^{\prime}$ methylation of cytosine $(\mathrm{mC})$ in the epithelial cells of the TEBs and iv) a dramatic loss of the histone H4 lysine 20 monomethylation (H4K20me1) mark in these cells (Leung and Ho, unpublished data). These early cellular and epigenetic changes correlate tightly with the dramatic increase in DMBA-induced tumor incidence from $45 \%$ in the HFB diet group to $90 \%$ in the HFB + $25 \mu \mathrm{g} / \mathrm{kg}$ body weight group. Importantly, these changes are non-monotonic with respect to the dose of BPA exposure exhibiting an inverted U-shape. Additionally, new data demonstrated that a high-fat butter and high-fat safflower oil diet has a greater effect than a high-fat olive oil diet in terms of promoting a response to BPA (Leung and Ho, unpublished data).

In summary, we have established an interesting animal model system to study the underpinning epigenetic mechanisms mediating the interaction between lifestyle factors and EDC exposure (Fig. 2). This has

Published by Bioscientifica Ltd. 
revealed the first evidence, to our knowledge, in support of the hypothesis that 'gestation is a critical window for dietary fatty acids-BPA interaction that reprograms the mammary epigenome, resulting in aberrant gene expression and increased breast cancer risk in adulthood'.

\section{Phytoestrogens}

Often referred to as 'dietary estrogens', phytoestrogens comprise a number of plant-derived xenoestrogens which function like the female sex hormone and are introduced into the body by consuming phytoestrogenic plants (Cos et al. 2003). Their structural similarity to estradiol means that they may exert a diverse range of estrogenic or antiestrogenic actions; however, there is some contention as to whether a diet rich in phytoestrogens is protective or detrimental to human health. Over 100 molecules have been identified as phytoestrogens, and these are broadly divided into four categories based on the chemical structure: isoflavones, lignans, coumestans and stilbens.

Phytoestrogens are able to bind differentially to both the ER $\alpha$ and ER $\beta$ receptors (Maggiolini et al. 2001, Morito et al. 2002), and as such their effect on breast cancer risk and development has been investigated in both epidemiological and experimental studies. Isoflavones, namely genistein which is found in soybeans, have been a particular focus of studies, with some suggesting that the high intake of soy-based products in Asian populations may be the reason for the lower lifetime breast cancer rates compared with Caucasian American women (Lipworth et al. 1999). This has been substantiated in numerous epidemiological studies demonstrating that a high soy diet or supplementation reduced breast cancer risk in women (Trock et al. 2006). Animal studies have revealed that

Hypothesis:

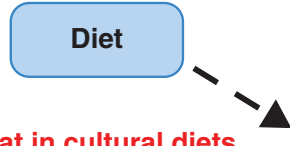

In utero exposure
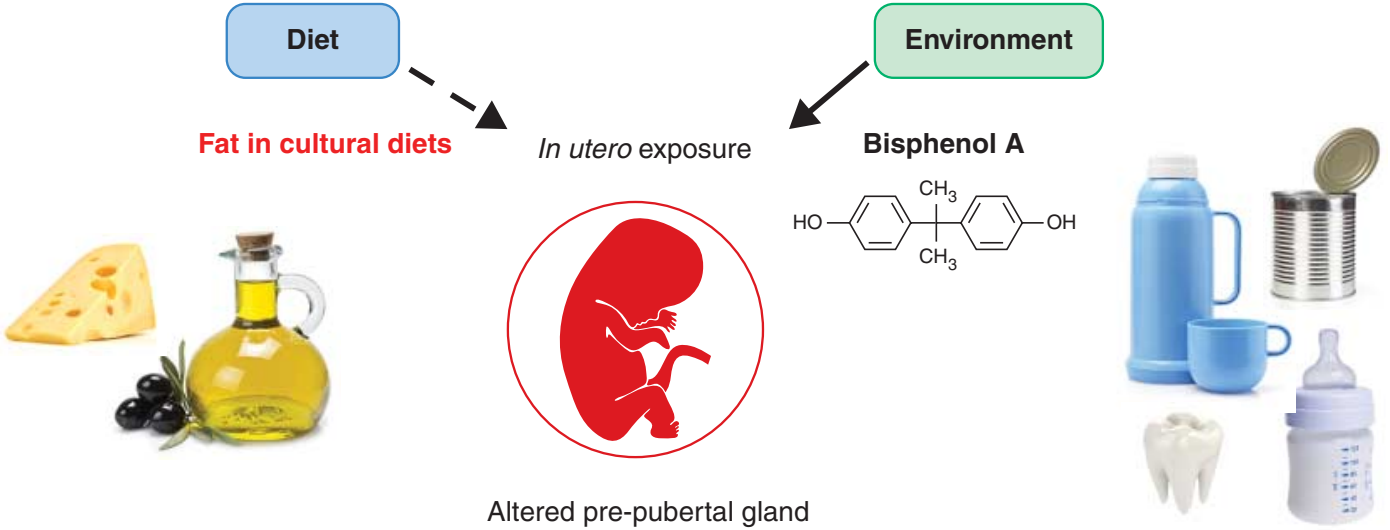

Altered pre-pubertal gland
development and cancer susceptibility
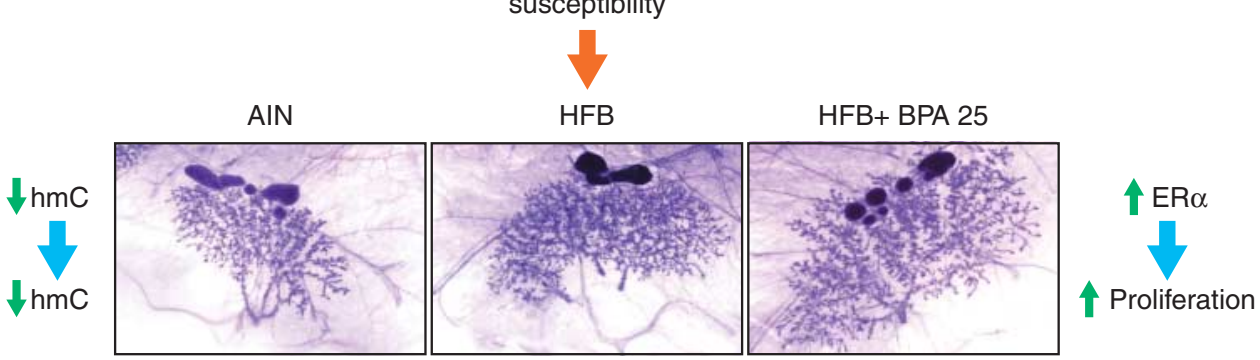

Increased number of terminal end buds in day 21 mammary glands

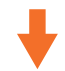

Increased mammary tumor incidence in adulthood

\section{Figure 2}

Synergistic effects of in utero exposure to high-fat diet and BPA exposure in increasing mammary tumor incidence in adult life. The dams were fed with high-fat butter (HFB) \pm BPA (2.5-2500 $\mu \mathrm{g} / \mathrm{kg}$ body weight) during acclimation and gestation periods. HFB $+25 \mu \mathrm{g} / \mathrm{kg}$ body weight produced the maximal synergistic effects of i) the increased number of terminal end

(C) 2014 Society for Endocrinology Printed in Great Britain buds (TEBs), estrogen receptor $\alpha(E R \alpha)$, epithelial cell proliferation, and significant loss of $5^{\prime}$ hydroxymethylation of cytosine $(\mathrm{hmC})$ and $5^{\prime}$ methylation of cytosine $(\mathrm{mC})$ in the epithelial cells of the TEBs; and ii) increased tumor incidence in the HFB + BPA group when compared with the BPA (or the control-diet AIN). 
exposure to isoflavones, namely genistein, in utero through to adulthood has distinct effects on mammary development, both increasing later-life breast cancer risk (Hilakivi-Clarke et al. 1998a, 1999a) and protection against chemical carcinogen-induced mammary tumors (Lamartiniere et al. 1995, Hilakivi-Clarke et al. 1999b, Pei et al. 2003, Su et al. 2007). Conversely, in vitro studies have indicated that high doses of genistein may potentiate cell proliferation in estrogen-dependent tumors (Kao et al. 1998).

Clearly, the occurrence of protective or detrimental effects of isoflavones on mammary tissues may depend on the application dose and time of life. Genistein administered to pregnant dams may increase the risk of mammary cancer in female rat offspring (Hilakivi-Clarke et al. 1999a), whereas prepubertal exposure reduces the risk (HilakiviClarke et al. 1999b). Furthermore, in utero exposure to genistein may program the mammary gland and alter susceptibility to cancer later in life (De Assis \& HilakiviClarke 2006), but in utero exposure to soy protein isolate (SPI), but not to pure genistein, protects young adult rat offspring in the $\mathrm{N}$-nitroso- $\mathrm{N}$-methylurea (NMU)-induced mammary carcinogenesis model (Su et al. 2007). Interestingly, adult-life SPI exposure also decreases the tumor incidence but elicits higher tumor grades, a feature not observed in in utero-exposed rats alone (Su et al. 2007).

A number of studies have demonstrated that phytoestrogens may play a role in altering the epigenome in the breast and other tissues. Treatment of ER-positive and ER-negative breast cancer cell lines with the isoflavones, genistein and daidzein, appears to reverse DNA hypermethylation and thus restore expression of the tumor suppressors, BRCA1 and BRCA2 (Bosviel et al. 2012). Genistein and the tomato phytoestrogen, lycopene, also show demethylating effects on the promoter region of the glutathione $S$-transferase pi-1 (GSTP1) gene, a tumor suppressor implicated in breast cancer development (King-Batoon et al. 2008). Other genes known to be targets of isoflavone-induced promoter demethylation in breast epithelial cells are RARß2 (RARB) and CCND2 (Qin et al. 2009). Mechanistically, this could be through genistein repressing the expression and activity of all three DNA methyltransferase enzymes in breast cancer cells, leading to a depletion of de novo methylation and maintenance of DNA methylation (Li et al. 2009). Repression of DNMT activity is also thought to be the mechanism behind resveratrol-mediated reactivation of breast cancerassociated tumor suppressor genes (Paluszczak et al. 2010). Resveratrol also promotes differential binding of the methyl-binding-domain protein 2 to the promoter of
BRCA1, preventing silencing of the gene in MCF-7 ER-positive breast cancer cells (Papoutsis et al. 2010).

A number of isoflavones have also been found to alter the histone methylation and acetylation signature in breast cancer cell lines (Jawaid et al. 2010, Dagdemir et al. 2013). Altered miRNA expression in response to isoflavones and resveratrol has been well demonstrated in cancers of the prostate, pancreas and ovaries (Li et al. 2010, Sheth et al. 2012, Chiyomaru et al. 2013, Xu et al. 2013); however, there has been limited work done to elucidate miRNA regulation by phytoestrogens in the breast. In one study, miR-141 and miR-200c were upregulated by resveratrol in a mouse xenograft model to limit the population of cancer stem cells (Hagiwara et al. 2012). Additionally, a number of other tumor-suppressive miRNAs including miR-16 and miR-143 were upregulated by resveratrol in breast cancer cell lines (Hagiwara et al. 2012).

\section{Diethylstilbestrol}

Diethylstilbestrol (DES) was prescribed to millions of women up until the early 1970s, and although it has since been banned the health consequences of its use are now becoming clear in later generations. DES was used to prevent miscarriages in the first trimester, treat breast and prostate cancers, inhibit lactation, stunt the growth of rapidly growing girls and control abnormal gynecological bleeding. It was also used in the feed of chickens and cattle to accelerate growth and production of lean meat until the late 1970s (Harris \& Waring 2012). All uses of DES in humans and animals were discontinued once it was established as a human carcinogen in a study linking cases of the rare vaginal clear cell carcinoma to daughters of mothers treated with DES during pregnancy (Herbst et al. 1971). The basis for the carcinogenic effects of DES is through its mimicking of estrogenic effects due to its design as a synthetic non-steroidal estrogen with a structure very close to that of estradiol.

In humans, DES exposure during in utero development has been associated with a number of later-life complications, including infertility, pregnancy complications, early menopause and cervical cancer (Hoover et al. 2011). A cohort study comparing women who were exposed in utero to DES with those born to mothers not at any stage given DES found that there was also a statistically significant increase in the risk of breast cancer development, but only for women over the age of 40 . There was also an increased occurrence of breast cancer in mothers

Published by Bioscientifica Ltd. 
who were given DES during pregnancy, although this was not evident until decades after initial treatment (Troisi et al. 2007). A number of animal studies have been performed to further explore the link between DES exposure and breast cancer. Female rats born to mothers that had received injections of DES during pregnancy displayed increased rates of breast tumor incidence and tumor multiplicity both with and without chemically induced carcinogenesis with DMBA (Boylan \& Calhoon 1979, Rothschild et al. 1987). In the mammary epithelial cell line MCF10F, DES exerts its carcinogenic effects by forming depurinating adducts with the DNA, predisposing these sites to mutations that may result in tumorigenesis (Hinrichs et al. 2011). Women exposed to DES in utero, however, lack genomic instability in normal or breast cancer tissue samples, indicating that the consequences of DES exposure may be mediated by the proliferative effects of estrogen (Larson et al. 2006).

Increasing evidence has implicated a role for epigenetics in DES-related mammary carcinogenesis. While there have been few studies examining epigenetic alterations by DES in mammary tissue, evidence can be drawn from other tissues in which estrogenic effects cause a predisposition to tumor development. In the mouse uterus, Dnmt1 expression is increased with DES exposure, resulting in alterations in genome methylation patterns (Sato et al. 2009). Hox genes, Fos and Nsbp1 (Hmgn5) are among the genes with altered methylation patterns in the uterus or endometrium of animal model offspring born to mothers exposed to DES (Li et al. 2003, Tang et al. 2008, Bromer et al. 2009). DES increased global levels of histone H3 trimethylation by increasing the activity of the histone methyltransferase enzyme, enhancer of zeste homologue 2 (EZH2), in ER-positive MCF-7 breast cancer cell lines and mammary tissues of mice exposed in utero to DES (Doherty et al. 2010).

ncRNA mechanisms may also play a role in DESmediated breast cancer development, as experimental exposure of epithelial progenitor cells to DES caused a differential expression profile in $9.1 \%$ of miRNAs screened. In particular, miR-9-3 was epigenetically silenced, and this led to promotion of cell proliferation via disordered regulation of the p53-mediated apoptotic pathway (Hsu et al. 2009).

Though limited evidence thus far exists to support an epigenetic basis for DES-induced breast cancer risk, studies in breast and other tissues provide a solid basis for further investigation of global epigenetic changes in the breasts of offspring exposed in utero to DES.

\section{2,3,7,8-tetrachloridibenzo-p-dioxin}

A well-known organochlorine, 2,3,7,8-tetrachloridibenzop-dioxin, or TCDD, is a pollutant byproduct of combustion and manufacture of chemicals. It has been detected in Agent Orange, the herbicide of choice for the United States Army in its bombings during the Vietnam War, thus exposing many troops and civilians to this endocrine disruptor (Kahn et al. 1988). Due to its long half-life of seven to eight years and its lipophilic chemical properties, TCDD tends to accumulate in both the environment and human bodies (Ogura et al. 2004). TCDD binds with high affinity to the aromatic hydrocarbon receptor (AhR) and is classified as an endocrine disruptor with strong anti-estrogenic properties (Jenkins et al. 2007).

TCDD has been associated with many adverse health consequences that have been characterized as a result of Agent Orange exposure during the Vietnam War, including congenital birth defects, pregnancy loss and increased rates of cancer (Le \& Johansson 2001). As TCDD is a lipophilic compound, it has been shown to accumulate in the adipose tissue of humans, leading to a particular concern about its potential role in the promotion of breast cancer. Studies in rats have revealed that gestational and lactational exposure to TCDD resulted in permanent alterations in the development of the mammary epithelium of female offspring. These rats displayed delayed maturation of mammary structures and multiple immature undifferentiated structures, leading to an increased susceptibility to chemical-carcinogen-induced tumorigenesis (Fenton et al. 2002). An increase in the number of TEBs coupled with a decrease in the number of lobules of rats exposed prenatally to TCDD has also been reported (Lewis et al. 2001). At the molecular level, studies using a Holtzman rats model demonstrated that TCDD may be acting systemically through lower rates of estradiol production and elevation in the expression of Esr1 mRNA in the breast, as well as in the uterus and ovaries (Chaffin et al. 1996).

A number of epidemiological studies have also been carried out to determine whether TCDD has a measurable impact on breast cancer risk in humans. A chemical explosion in Seveso, Italy, in 1976 resulted in exceedingly high levels of exposure to TCDD among the local residents. A retrospective study performed in 2008 examined women who were premenopausal at the time of the explosion and found that there was a measurable but not statistically significant increased prevalence of breast cancer diagnoses when compared with the general population (Warner et al. 2011). Similarly, female workers

Published by Bioscientifica Ltd. 
at a chemical pesticide plant who were occupationally exposed to high levels of TCDD showed significantly higher prevalence of breast cancer (Manuwald et al. 2012).

Evidence exists to indicate that TCDD has a significant effect on the epigenome in the breast and other tissues. TCDD increased association of DNMT1, histone methylation markers and methyl-binding-domain protein 2 to the promoter region of $B C R A 1$, leading to hypermethylation and epigenetic silencing in breast cancer cell lines (Papoutsis et al. 2010). In a follow-up study by the same group, Sprague-Dawley rats treated during gestation with TCDD alone or in combination with the dietary AhR antagonist, resveratrol, increased the number of TEBs and reduced Brca1 expression in mammary tissue of offspring, a process induced by occupancy of Brca1 by DNMT1 and CpG methylation (Papoutsis et al. 2013). Interestingly, these changes were partially overridden by pre-exposure to resveratrol. In keratinocytes, TCDD is able to immortalize cell division through repression of $p 53(\operatorname{Trp53})$ and p16INK4a (Cdkn2a) expression. This is via promotermethylation-mediated gene silencing, indicating that epigenetic silencing of key tumor suppressors may be a factor in breast cancer development (Ray \& Swanson 2004). Both these genes and their regulatory components are known to be hypermethylated and silenced in breast cancer (Barekati et al. 2010, Lee et al. 2012), and these data indicate that TCDD may be one of the causes of epigenetic silencing and tumor development.

TCDD significantly altered the methylome in the sperm of rats three generations after in utero exposure. While increased breast cancer rates were not among the observed effects, increased incidence of prostate disease, polycystic ovarian disease and pubertal abnormalities was observed, indicating that endocrine mechanisms were affected by TCDD-induced methylation changes (Manikkam et al. 2012). In utero treatment of developing mouse embryos with TCDD decreased expression of the imprinted genes, $H 19$ and Igf2, through increased methylation in their promoter region. This was correlated with the increased activity of the DNA methyltransferase enzymes (Wu et al. 2004). miRNA regulation has been investigated as a potential mechanism for TCDD-mediated gene expression changes in the rat liver; however, no significant changes in miRNA levels were detected, indicating that TCDD does not affect the miRNA levels (Moffat et al. 2007).

Taken together, previous studies indicate the potential for TCDD to exert its carcinogenic effects on the breast through epigenetic mechanisms; however, more focused work needs to be done in breast tissue to expand on this hypothesis, particularly when deciphering developmental effects vs those in adults.

\section{Polychlorinated biphenyls}

Polychlorinated biphenyls (PCBs) are complex industrial chemicals historically used as coolants or heat-transfer agents in electrical transformers. PCBs are also used for diverse chemical applications such as plasticizers, solvents, hydraulic fluids and printing inks (reviewed in Crinnion (2011)). PCBs, although their production was banned in the USA in the late 1970s, constitute persistent organic pollutants (POPs) due to their stability, high lipophilicity and prevalence in the environment. PCBs have been found to be accumulated in breast adipose tissue (Rogan 1996, Petreas et al. 2011), and as a result transferred into breast milk (Dewailly et al. 1996). While, in recent years, a number of animal and human studies have indicated that PCBs can adversely affect thyroid functions (Salay \& Garabrant 2009), epidemiological studies linking PCBs to breast cancer have been controversial with results of some studies indicating positive associations (Moysich et al. 1998, Dorgan et al. 1999, Millikan et al. 2000) and those of others failing to demonstrate any risk (Hoyer et al. 1998, Zheng et al. 2000, Laden et al. 2001). A review of the epidemiological literature examining possible links between PCB exposures and breast cancer has concluded that findings are inconsistent across studies and indicate that there is no association with increased risk (Brody et al. 2007, Golden \& Kimbrough 2009). However, as also noted in dichlorodiphenyltrichloroethane (DDT) epidemiological studies (Cohn 2011) (discussed later in this review), the methods used in most studies do not account for exposures during earlier periods of development when mammary tissue is particularly sensitive to the toxic effects of many environmental chemicals such as PCBs (Verner et al. 2011).

PCBs interfere with estrogen metabolism (Korach et al. 1988, Connor et al. 1997), elevate the amount of bioavailable estradiol (Gellert 1978) and synergistically regulate estrogen-responsive genes (Jansen et al. 1993). In vitro studies of the estrogenic effects of PCBs have provided conflicting data, with some studies demonstrating an increase in breast cancer cellular proliferation and others showing no or opposing effects (Du et al. 2000, Bonefeld-Jorgensen et al. 2001, Oenga et al. 2004, Radice et al. 2008, Ptak et al. 2011). More recent findings have revealed roles of PCBs in breast cancer cell metastasis (Liu et al. 2010) and metabolism (Venkatesha et al. 2010).

PCBs have identified as EDCs capable of influencing epigenetic modifying processes. In vivo studies in rats have

Published by Bioscientifica Ltd. 
demonstrated that in utero and lactational administration of combinations of PCBs decreases the availability of the universal methyl donor $S$-adenosylmethionine (SAM), Dnmt1 mRNA abundance and DNA methylation in liver cells (Desaulniers et al. 2009). It was found that PCBs decreased global genome DNA methylation and CpG methylation of the promoter of the p16INK4a gene (Desaulniers et al . 2009). The ability of PCBs to reduce DNA methylation in animals may also be reflected in humans. Two studies have revealed low levels of global DNA methylation in a population exposed to low doses of POPs (Kim et al. 2010) and in another in areas of the Arctic exposed to high doses (Rusiecki et al. 2008). The reduction in DNA methylation levels by PCBs may well be correlated with the increased transcriptional activity of target genes in breast cancer; indeed, PCBs have also found to reduce levels of H4K16Ac histone post-translational modifications (Casati et al. 2012), a hallmark of human cancer (Fraga et al. 2005). Conversely, in utero exposure to PCBs in rats has been shown to reduce promoter methylation of the tumor suppressor gene p16 (Cdkn2a) in hepatic cells (Desaulniers et al. 2009), but whether this occurs in the breast is unknown.

Obesity is a leading risk factor in the development of breast cancer, particularly in postmenopausal women where breast adipose tissue adjacent to an ER-positive tumor becomes the major source of local estrogen (Simpson et al. 1997). The increase in intratumoral estrogen production coincides with the elevated levels of expression and activity in breast adipose stromal cells of the aromatase gene (CYP19A1) (Bulun et al. 1993), which encodes the key enzyme involved in the conversion of androgens to estrogens. We have previously identified an inverse relationship between DNA methylation and CYP19A1 expression in breast adipose stromal cells (Knower et al. 2010) and described epigenetics as a potential contributory factor in maintaining intratumoral estrogen levels in the breast (Knower et al. 2013). Given that PCBs accumulate in breast adipose tissue and reduce global DNA methylation, they may have a role in the sustained and increased levels of intratumoral estrogens. Indeed, there are numerous studies demonstrating that PCBs alter the expression of aromatase and other sex steroid metabolism enzymes in human (Drenth et al. 1998, Wojtowicz et al. 2005, Li 2007, Dhooge et al. 2011, Karmaus et al. 2011, Warner et al. 2012) and animal models (Hany et al. 1999, Kaya et al. 2002). In one instance, methylsulfonyl PCB metabolites (MeSO2-PCBs) were found to inhibit aromatase expression and activity in breast adipose fibroblasts (Heneweer et al. 2005).
This study, however, only measured CYP19A1 transcripts derived from the adipose-tissue-specific promoter I.4 and did not account for those derived from the breast-cancerspecific promoter II that make up $80 \%$ of the transcripts in a tumor. Whether PCBs influence sex steroid biosynthesis in the breast via epigenetic mechanisms is an area yet to be fully investigated.

\section{Polycyclic aromatic hydrocarbons}

Polycyclic aromatic hydrocarbons (PAHs) are the most widespread organic compounds found in the environment with endocrine-disrupting properties affecting hormone signaling by binding to receptors and having estrogenic properties (Santodonato 1997, Li et al. 2012, Sievers et al. 2013). PAHs are formed during the incomplete combustion of many substances including coals, crude oil, wood, gasoline, foods and cigarettes (Simon et al. 2008). As a consequence, higher exposures to PAHs occur among selected occupations such as firefighters and coke oven, aluminum and foundry workers (Rothman et al. 1993a,b, Mastrangelo et al. 1996). PAHs are lipophilic compounds of high stability, acting as carcinogens with genotoxic and mutagenic properties in many diseases, such as lung cancer (Boffetta et al. 1997). In breast, this is most reflected by the administration of the carcinogen DMBA in rodents to determine the effects of additional chemicals or alterations in gene expression transgenic models on tumor susceptibility; however, the carcinogenic properties of PAHs in human breast cancer remain unclear (Gammon \& Santella 2008). Insufficient detoxification and metabolism of PAHs in the body results in the formation of PAH-DNA adducts in specific cell types (Pratt et al. 2011). Epidemiological studies have reported an association between PAH-DNA adducts and breast cancer incidence (Li et al. 1996, Rundle et al. 2000, Gammon et al. 2002, 2004). In contrast, a strong correlation between PAH-DNA adducts and breast cancer mortality was not observed (Sagiv et al. 2009). However, as the power of this study was limited, further investigation is warranted among larger populations with more outcomes, particularly among premenopausal women where PAHrelated mortality may be higher.

PAH exposure during early embryonic development is a critical determinant of susceptibility to epigenetic alterations. Prenatal exposure to PAHs increases PAH-DNA adducts and alters DNA methylation, mediating genespecific promoter DNA methylation changes in such instances as asthma (Perera et al. 2009, Tang et al. 2012a). In addition, findings have indicated that PAH-induced DNA adducts may preferentially form near methylated

Published by Bioscientifica Lto. 
CpG sites (Denissenko et al. 1996, Chen et al. 1998, Tretyakova et al. 2002).

A number of studies have indicated a positive correlation between passive or active smoking and an increased breast cancer risk (Luo et al. 2011, Gaudet et al. 2013). Conflicting evidence has even indicated hormonereceptor-specific increases in risk, with separate investigations linking smoking to increased risk of developing ER-negative and ER-positive breast tumors (Manjer et al. 2001, Al-Delaimy et al. 2004). PAH chemicals found in cigarette smoke cause changes in the epigenetic landscape and, although limited evidence exists regarding breast tissues, may contribute to the increased risk of breast cancer observed in smokers. An epigenome-wide association study comparing the peripheral blood DNA methylation of smokers vs non-smokers revealed that an intergenic CpG island at the 2q37.1 locus was positively associated with breast cancer risk (Shenker et al. 2013), although whether PAHs are directly involved with its methylation status has not been determined. In normal human bronchial epithelial cells treated with nicotinederived nitrosamine ketone, a chemical found in cigarette smoke, several stress-induced ncRNA transcripts were found to be upregulated. These transcripts are also upregulated in a number of breast cancer cell lines, indicating that cigarette smoke has the capacity to upregulate ncRNAs in breast cancer (Silva et al. 2010).

The PAH benzo[a]pyrene (BaP), mainly sourced from wood burning, but also detected in cigarettes, has been shown to have many epigenetic-disrupting properties in a number of human and animal models (Wilson \& Jones 1983, Herbstman et al. 2012, Liang et al. 2012, Fang et al. 2013). DNA adducts involving the BaP metabolite, BaP diolepoxide (BPDE), have been identified in breast epithelial cells and human breast milk, demonstrating that $\mathrm{BaP}$ penetrates ductal breast epithelial cells, where most breast cancers are thought to arise (Li et al. 1996, Gorlewska-Roberts et al. 2002, Thompson et al. 2002). In vitro studies using human breast cancer cell lines have demonstrated a number of facets of BaP action, including DNA mismatch repair (Chen et al. 2013), cell cycle (Hamouchene et al. 2011), metabolism (Spink et al. 2008) and invasion (Miller et al. 2005). Epigenomic studies in breast cells reveal that the actions of $\mathrm{BaP}$ are widespread, altering both DNA methylation and histone patterns (Bradley et al. 2007, Sadikovic et al. 2007, Sadikovic et al. 2008). While BaP is an EDC with strong links to the epigenome, the various and ubiquitous exposures of PAHs in the environment should lead future work into the exploration of different combinations of PAHs and their effect on the epigenome. Furthermore, evidence needs to be generated demonstrating whether the epigenetic effects of PAHs, such as BaP, are gene-specific for breast cancer susceptibility genes. The use of in vitro breast cancer models is a clear starting point; however, drawing associations with epidemiological data may prove to be a difficult process.

\section{Perfluorooctanoic acid}

Perfluorooctanoic acid (PFOA) is an environmentally ubiquitous chemical that has extensive industrial applications, including in surfactants, water proofing, insulating agents and dental products (reviewed in White et al. (2011a)). PFOA is a non-lipophilic protein-binding chemical with a half-life of 16-22 days in mice (Lou et al. 2009) and 2-4 years in humans (Seals et al. 2011). The ongoing exposure to PFOA in the environment is reflected by its detection in the serum of animals and all humans in the US population examined (Calafat et al. 2007a,b). The mechanisms of action of PFOA in disease states are unclear; however, many of the affected target tissues are endocrine-regulated, such as the immune system and thyroid (White et al. 2011a). This is further explained by a number of studies describing interactions of PFOA with nuclear hormone receptors such as the peroxisome proliferator-activated receptor $\alpha(P P A R \alpha(P P A R A))$, constitutive androstane receptor (CAR (NR1I3)), pregnane $\mathrm{X}$ receptor (PXR (NR1I2)) and the ER, where modulation of estrogen-responsive genes has been observed (Cheng \& Klaassen 2008, Rosen et al. 2008b, Bjork et al. 2011, Henry \& Fair 2013).

Epidemiological studies have indicated that PFOA may be associated with a reduced risk of breast cancer as it was found to be positively associated with delayed puberty, early menopause and preeclampsia (Knox et al. 2011, Lopez-Espinosa et al. 2011, Savitz et al. 2012), factors that have been shown to reduce breast cancer risk (Innes \& Byers 1999, Britt 2012). Recent data have however revealed a positive association between PFOA compounds and breast cancer risk in a small highly exposed Inuit population (Bonefeld-Jorgensen et al. 2011). More detailed examination of PFOAs in animal models revealed alterations in mammary gland development that may increase susceptibility to carcinogens. As part of these studies, prenatal PFOA exposure has been shown to delay mammary epithelial cell development, reduce ductal branching and TEB formation, increase stromal cell density, cause epithelial hyperplasia and elevate ER protein expression (White et al. 2007, 2009, 2011b,

Published by Bioscientifica Ltd. 
Zhao et al. 2010, Macon et al. 2011). The studies by White et al. (2011b) clearly demonstrated that the gestational and chronic adult exposure to PFOA across three generations altered mammary development. They showed that PFOAexposed F1 dams exhibited diminished lactational morphology and reduced gland development. Of note, F2 females with chronic low-dose drinking-water exposures, at concentrations approximating those found in contaminated human water supplies, also exhibited visibly slowed mammary gland differentiation.

Limited evidence exists for PFOA in the epigenetic regulation of genes involved in breast cancer. Prenatal exposure to perfluorooctanesulfonic acid, a perfluorinated compound similar to PFOA, has been associated with Gstp1 promoter hypermethylation in rats (Wan et al. 2010). While in utero PFOA exposure has been inversely correlated with cord serum global DNA methylation in humans (Guerrero-Preston et al. 2010), other in vitro studies have indicated that PFOA does not alter global DNA methylation levels in neuroblastoma, preadipocytes, mature adipocytes or liver cells (Tian et al. 2012, Bastos Sales et al. 2013). These findings indicate that PFOAmediated epigenetic effects may be gene-specific such as that seen on the promoter of the GSTP gene where hypermethylation following PFOA treatment in normal L02 liver cells is observed (Tian et al. 2012), a process that is also reflected in leukemia, prostate and liver cancer cells (Zhong et al. 2002, Nakayama et al. 2004, Karius et al. 2011). Therefore, the gene-specific epigenetic properties of PFOA are factors to be mindful of when assessing changes in gene expression following exposure, particularly in genomic studies where large subsets of genes have been shown to be modulated in the liver and lung (Guruge et al. 2006, Rosen et al. 2007, 2008a). Analysis by highthroughput screening of the epigenome-targeting gene promoters would therefore be the best measurement of PFOA epigenetic targets. Such a study has not been conducted using mouse or human breast models, however this line of investigation worthy of pursuance.

\section{DDT and DDE}

Dichlorodiphenyltrichloroethane (DDT) is a synthetic insecticide whose long half-life, extensive use and lipophilic nature have made it a prominent environmental contaminant bioaccumulating in fat stores of animals and humans (Kelly et al. 2004). Despite lowering the risk of malaria and typhoid, the use of DDT was banned in 1972 due to its effects on the environment and risks to human health. The DDT metabolite, 1,1-dichloro-2,2-bis(p-chlorophenyl)ethylene (DDE), continues to be detected in human serum at high concentrations (Cole et al. 2006). DDT and its metabolites, such as DDE, have been associated with human diseases including testicular tumors (McGlynn et al. 2008), type 2 diabetes (Codru et al. 2007), endometrial cancer (Hardell et al. 2004), pancreatic cancer (Porta et al. 2008) and breast cancer (Wolff et al. 1993, Safe \& Zacharewski 1997). Given the strong association with endocrine-related diseases, there is no doubt that DDT acts as a strong EDC, and despite the estrogenic properties of DDT being first documented over 50 years ago (Tullner 1961), its mechanistic actions remain a point of ongoing research. Epidemiological studies using the Child Health and Development Study (CHDS) birth cohort, however, show that exposure of women exposed during pregnancy is associated with breast cancer in mothers, altered reproductive function in daughters and testicular cancer in sons, with all of these outcomes suggested as possible targets of DDT exposure (Cohn et al. 2003, 2007, 2010, Eskenazi et al. 2009).

In vitro studies have demonstrated the ability of DDT to mimic estradiol by binding to $\mathrm{ER} \alpha$ and regulating breast cancer target genes (Klotz et al. 1996, Kuiper et al. 1998, Qin et al. 2011). DDT and its metabolites have also been shown to regulate estrogen target genes in ER $\alpha$-independent mechanisms (Frigo et al. 2002, 2006, Bratton et al. 2009, 2012). The estrogenic effects of DDT and its metabolites on breast cancer have also been described for animal models. Early work provided evidence that the DDT metabolite $o, p^{\prime}$-DDE enhanced mammary epithelium growth and proliferation (Brown \& Lamartiniere 1995) and tumor cell proliferation (Robison et al. 1985). In a recent study by Johnson et al. (2012), HER2/Neu mice with $p, p^{\prime}$-DDE metabolite implants were found to have increased mammary tumor growth; however, it was suggested that DDE exposure alone could not be the cause of tumorigenesis but rather that it is due hormonal contributions. Given that DDT metabolites are capable of increasing estrogen production through the upregulation of the aromatase gene in breast epithelial cells (Han et al. 2010), this is one potential mechanism for in vivo observations.

There have been limited investigations into the epigenetic actions of DDT and other metabolites. Of note are the findings that low doses of DDT reduce the expression of the Dnmt1 gene in the hypothalamus of young male rats, a process correlating with global hypomethylation and demethylation of $\mathrm{CpG}$ islands (Shutoh et al. 2009). Similar observations of global

Published by Bioscientifica Ltd. 
hypomethylation by DDT are also found in Greenlandic Inuit populations, as discussed in the aforementioned case for PCB exposure (Rusiecki et al. 2008). Recent work has also emerged describing the potential for DDT to play a prominent role in miRNA regulation in the breast (Tilghman et al. 2012). This research identified both common and distinct microRNA profiles induced by either estradiol, BPA or DDT in MCF-7 cells, supporting the notion that although EDCs may mimic estrogenic actions, their activity differs from that of the naturally occurring steroid hormone.

The epigenetic actions of EDCs in disease states, including breast cancer, are largely dependent on earlylife exposure. In the case of DDE, significant findings have associated prenatal exposure to altered steroid hormone metabolism. Focusing on the adult female offspring of the Michigan Fisheater Cohort exposed to elevated levels of organochlorines in fish consumed before or during gestation (1973-1991) (Karmaus et al. 2004, 2009), the expression of the genes 17-a-hydroxylase (CYP17A1), CYP19A1, and estrogen receptor $\alpha$ and $\beta$ (ESR1 and ESR2) was determined and found to be associated with prenatal exposure to $\mathrm{DDE}$ and $\mathrm{PCBs}$ and concurrent serum concentration of DDE and PCBs (Karmaus et al. 2011). Prenatal and concurrent DDE levels were significantly related to increased gene expression of aromatase but not of 17-a-hydroxylase, ESR1 or ESR2. Given that DDT and DDE are accumulated in breast cancer adipose tissue (Ociepa-Zawal et al. 2010) and the fact that aromatase is under epigenetic control in the same tissue (Knower et al. 2010), the possibility of an epigenetic association resulting in increased intratumoral estrogen caused by DDT and it metabolites may exist. Furthermore, if future studies support those of Karmaus et al. (2011), gestational exposure to EDCs may result in long-term alterations in gene expression that can still be detected several decades on.

\section{Vinclozolin}

Vinclozolin, like many of the EDCs discussed already, is a lipophilic compound capable of bioaccumulating in tissues. As a pesticide it is used on fruits and vegetables to protect against several fungi, meaning that most exposure comes through the consumption of residual contamination in foods and drinking water. The endocrinedisrupting properties of vinclozolin and its metabolites were first described for the male reproductive system, where it acts as an antiandrogen (Gray et al. 1994, Kelce et al. 1994). Subsequent works have demonstrated several actions of vinclozolin as an antiandrogen, including reducing prostate weight (Monosson et al. 1999), modulating sex steroid levels (Quignot et al. 2012) and elevating the prevalence of tumors in the prostate and testis (Anway et al. 2006). In the female, vinclozolin exposure in rats results in the formation of mammary tumors (Anway et al. 2006) and disrupts mammary gland development, where epithelial branching and TEBs are increased compared with controls (El Sheikh Saad et al. 2011, 2013). However, very few epidemiological studies have been performed on the association of vinclozolin exposure with breast cancer.

A number of studies have been conducted, primarily by Michael Skinner and colleagues, investigating the transgenerational epigenetic effects of vinclozolin. Vinclozolin has been shown to promote an epigenetic alteration in the germ line that appears to transmit a transgenerational disease state (Anway et al. 2005). In this rat model, breast cancer was observed in $10 \%$ of vinclozolin-exposed F1-F4 generational rats but absent in control animals (Anway et al. 2006). While transcriptome profiling has been conducted on this animal model, published results are focused on male phenotypes including those of prostate cancer (Anway \& Skinner 2008). Therefore, the transgenerational epigenetic targets resulting in breast tumors are yet to be fully characterized but warrant further investigation.

\section{Concluding remarks}

In this review, we have focused on EDCs that alter the epigenome and potentially alter mammary development and increase breast cancer risk. However, the health outcomes resulting from environmental exposures are highly varied and complex. The concept of defining an environmental exposure as an 'exposome' has recently emerged to describe the summation of all exposures and individual experiences over their lifetime, from conception to advanced age (Wild 2005). Together with the 'interactome' (e.g. genetics, epigenetics, proteomics and metabolomics), the exposome adds an additional layer of complexity to molecular epidemiological studies trying to derive associations between EDCs and common diseases, such as breast cancer. To advance the field of environmental epigenetics, future studies therefore need to consider the multiple corroborations at play. Emphasis needs to be placed on the development of animal models that mimic human diseases. In the future, such models may be advanced to the point of addressing common interactions between lifestyle factors, such as circadian rhythms, diet and physical activities, as modifiers of

Published by Bioscientifica Ltd. 
exposure that may yield critical information on human variability dependent on epigenetic reprogramming. The potential reversibility of epigenetics provides opportunities for the primary prevention of environmentally induced diseases. However, measuring these epigenetic changes over an individual's lifetime will prove challenging; therefore, the development of environmental epigenetic biomarkers may be more suitable for the prediction of future disease risk, including that for breast cancer.

\section{Declaration of interest}

The authors declare that there is no conflict of interest that could be perceived as prejudicing the impartiality of the review.

\section{Funding}

This work was supported by the National Health and Medical Research Council of Australia through fellowships to C D Clyne (\#338518) and National Health and Medical Research Council (NHMRC) Independent Research Institutes Infrastructure Support Scheme (IRIISS), the Victorian State Government through the Victoria Cancer Agency funding of the Victoria Breast Cancer Research Consortium and the Victorian Government's Operational Infrastructure Support Program. K C Knower is co-supported by Cancer Australia and Cure Cancer Australia Foundation - Priority-driven Collaborative Cancer Young-Investigator Research Scheme. S Q To is supported by a Monash University Postgraduate Publications Award and Cancer Council Victoria Postdoctoral Cancer Research Fellowship. PHI Data Audit \#13-25.

\section{References}

Al-Delaimy WK, Cho E, Chen WY, Colditz G \& Willet WC 2004 A prospective study of smoking and risk of breast cancer in young adult women. Cancer Epidemiology, Biomarkers \& Prevention 13 398-404.

Anway MD \& Skinner MK 2008 Transgenerational effects of the endocrine disruptor vinclozolin on the prostate transcriptome and adult onset disease. Prostate 68 517-529. (doi:10.1002/pros.20724)

Anway MD, Cupp AS, Uzumcu M \& Skinner MK 2005 Epigenetic transgenerational actions of endocrine disruptors and male fertility. Science 308 1466-1469. (doi:10.1126/science.1108190)

Anway MD, Leathers C \& Skinner MK 2006 Endocrine disruptor vinclozolin induced epigenetic transgenerational adult-onset disease. Endocrinology 147 5515-5523. (doi:10.1210/en.2006-0640)

Ayyanan A, Laribi O, Schuepbach-Mallepell S, Schrick C, Gutierrez M, Tanos T, Lefebvre G, Rougemont J, Yalcin-Ozuysal O \& Brisken C 2011 Perinatal exposure to bisphenol A increases adult mammary gland progesterone response and cell number. Molecular Endocrinology 25 1915-1923. (doi:10.1210/me.2011-1129)

Barekati Z, Radpour R, Kohler C, Zhang B, Toniolo P, Lenner P, Lv Q Zheng H \& Zhong XY 2010 Methylation profile of TP53 regulatory pathway and mtDNA alterations in breast cancer patients lacking TP53 mutations. Human Molecular Genetics 19 2936-2946. (doi:10.1093/ hmg/ddq199)

Bastos Sales L, Kamstra JH, Cenijn PH, van Rijt LS, Hamers T \& Legler J 2013 Effects of endocrine disrupting chemicals on in vitro global DNA methylation and adipocyte differentiation. Toxicology In Vitro $\mathbf{2 7}$ 1634-1643. (doi:10.1016/j.tiv.2013.04.005)

Bedford MT \& Clarke SG 2009 Protein arginine methylation in mammals: who, what, and why. Molecular Cell 33 1-13. (doi:10.1016/j.molcel. 2008.12.013)
Bhutani N, Burns DM \& Blau HM 2011 DNA demethylation dynamics. Cell 146 866-872. (doi:10.1016/j.cell.2011.08.042)

Bjork JA, Butenhoff JL \& Wallace KB 2011 Multiplicity of nuclear receptor activation by PFOA and PFOS in primary human and rodent hepatocytes. Toxicology 288 8-17. (doi:10.1016/j.tox.2011.06.012)

Boffetta P, Jourenkova N \& Gustavsson P 1997 Cancer risk from occupational and environmental exposure to polycyclic aromatic hydrocarbons. Cancer Causes \& Control 8 444-472. (doi:10.1023/ A:1018465507029)

Bogdanovic O \& Veenstra GJ 2009 DNA methylation and methyl-CpG binding proteins: developmental requirements and function. Chromosoma 118 549-565. (doi:10.1007/s00412-009-0221-9)

Bonefeld-Jorgensen EC, Andersen HR, Rasmussen TH \& Vinggaard AM 2001 Effect of highly bioaccumulated polychlorinated biphenyl congeners on estrogen and androgen receptor activity. Toxicology 158 141-153. (doi:10.1016/S0300-483X(00)00368-1)

Bonefeld-Jorgensen EC, Long M, Bossi R, Ayotte P, Asmund G, Kruger T, Ghisari M, Mulvad G, Kern P, Nzulumiki P et al. 2011 Perfluorinated compounds are related to breast cancer risk in Greenlandic Inuit: a case control study. Environmental Health 10 88. (doi:10.1186/1476069X-10-88)

Bosviel R, Dumollard E, Dechelotte P, Bignon YJ \& Bernard-Gallon D 2012 Can soy phytoestrogens decrease DNA methylation in BRCA1 and BRCA2 oncosuppressor genes in breast cancer? OMICS: a Journal of Integrative Biology 16 235-244. (doi:10.1089/omi.2011.0105)

Boyes J \& Bird A 1992 Repression of genes by DNA methylation depends on CpG density and promoter strength: evidence for involvement of a methyl-CpG binding protein. EMBO Journal 11 327-333.

Boylan ES \& Calhoon RE 1979 Mammary tumorigenesis in the rat following prenatal exposure to diethylstilbestrol and postnatal treatment with 7,12-dimethylbenz[a]anthracene. Journal of Toxicology and Environmental Health 5 1059-1071. (doi:10.1080/1528739790 9529814)

Bradley C, van der Meer R, Roodi N, Yan H, Chandrasekharan MB, Sun ZW, Mernaugh RL \& Parl FF 2007 Carcinogen-induced histone alteration in normal human mammary epithelial cells. Carcinogenesis 28 2184-2192. (doi:10.1093/carcin/bgm100)

Bratton MR, Frigo DE, Vigh-Conrad KA, Fan D, Wadsworth S, McLachlan JA \& Burow ME 2009 Organochlorine-mediated potentiation of the general coactivator p300 through p38 mitogen-activated protein kinase. Carcinogenesis 30 106-113. (doi:10.1093/carcin/bgn213)

Bratton MR, Frigo DE, Segar HC, Nephew KP, McLachlan JA, Wiese TE \& Burow ME 2012 The organochlorine $o, p^{\prime}$-DDT plays a role in coactivator-mediated MAPK crosstalk in MCF-7 breast cancer cells. Environmental Health Perspectives 120 1291-1296. (doi:10.1289/ehp. 1104296)

Britt K 2012 Menarche, menopause, and breast cancer risk. Lancet Oncology 13 1071-1072. (doi:10.1016/S1470-2045(12)70456-4)

Brody JG, Moysich KB, Humblet O, Attfield KR, Beehler GP \& Rudel RA 2007 Environmental pollutants and breast cancer: epidemiologic studies. Cancer 109 2667-2711. (doi:10.1002/cncr.22655)

Bromer JG, Wu J, Zhou Y \& Taylor HS 2009 Hypermethylation of homeobox A10 by in utero diethylstilbestrol exposure: an epigenetic mechanism for altered developmental programming. Endocrinology 150 3376-3382. (doi:10.1210/en.2009-0071)

Brown NM \& Lamartiniere CA 1995 Xenoestrogens alter mammary gland differentiation and cell proliferation in the rat. Environmental Health Perspectives 103 708-713.

Bulun SE, Price TM, Aitken J, Mahendroo MS \& Simpson ER 1993 A link between breast cancer and local estrogen biosynthesis suggested by quantification of breast adipose tissue aromatase cytochrome P450 transcripts using competitive polymerase chain reaction after reverse transcription. Journal of Clinical Endocrinology and Metabolism $7 \mathbf{7}$ 1622-1628. (doi:10.1210/jcem.77.6.8117355)

Calafat AM, Kuklenyik Z, Reidy JA, Caudill SP, Ekong J \& Needham LL 2005 Urinary concentrations of bisphenol A and 4-nonylphenol in a human

Published by Bioscientifica Ltd. 
reference population. Environmental Health Perspectives 113 391-395. (doi:10.1289/ehp.7534)

Calafat AM, Kuklenyik Z, Reidy JA, Caudill SP, Tully JS \& Needham LL $2007 a$ Serum concentrations of 11 polyfluoroalkyl compounds in the U.S. population: data from the national health and nutrition examination survey (NHANES). Environmental Science \& Technology 41 2237-2242. (doi:10.1021/es062686m)

Calafat AM, Wong LY, Kuklenyik Z, Reidy JA \& Needham LL 2007b Polyfluoroalkyl chemicals in the U.S. population: data from the National Health and Nutrition Examination Survey (NHANES) 2003-2004 and comparisons with NHANES 1999-2000. Environmental Health Perspectives 115 1596-1602. (doi:10.1289/ehp.10598)

Calafat AM, Ye X, Wong LY, Reidy JA \& Needham LL 2008 Exposure of the U.S. population to bisphenol A and 4-tertiary-octylphenol: 2003-2004. Environmental Health Perspectives 116 39-44. (doi:10.1289/ehp.10753)

Casati L, Sendra R, Colciago A, Negri-Cesi P, Berdasco M, Esteller M \& Celotti F 2012 Polychlorinated biphenyls affect histone modification pattern in early development of rats: a role for androgen receptor-dependent modulation? Epigenomics 4 101-112. (doi:10.2217/epi.11.110)

Chaffin CL, Peterson RE \& Hutz RJ 1996 In utero and lactational exposure of female Holtzman rats to 2,3,7,8-tetrachlorodibenzo-p-dioxin: modulation of the estrogen signal. Biology of Reproduction 55 62-67. (doi:10.1095/biolreprod55.1.62)

Chen JX, Zheng Y, West M \& Tang MS 1998 Carcinogens preferentially bind at methylated CpG in the p53 mutational hot spots. Cancer Research 58 2070-2075.

Chen Y, Huang C, Bai C, Gao H, Ma R, Liu X \& Dong Q 2013 Benzo[ $\alpha]$ pyrene repressed DNA mismatch repair in human breast cancer cells. Toxicology 304 167-172. (doi:10.1016/j.tox.2013.01.003)

Cheng X \& Klaassen CD 2008 Perfluorocarboxylic acids induce cytochrome P450 enzymes in mouse liver through activation of PPAR- $\alpha$ and CAR transcription factors. Toxicological Sciences 106 29-36. (doi:10.1093/ toxsci/kfn147)

Chiyomaru T, Yamamura S, Fukuhara S, Hidaka H, Majid S, Saini S, Arora S, Deng G, Shahryari V, Chang I et al. 2013 Genistein up-regulates tumor suppressor microRNA-574-3p in prostate cancer. PLoS ONE 8 e58929. (doi:10.1371/journal.pone.0058929)

Choudhary C, Kumar C, Gnad F, Nielsen ML, Rehman M, Walther TC, Olsen JV \& Mann M 2009 Lysine acetylation targets protein complexes and co-regulates major cellular functions. Science 325 834-840. (doi:10.1126/science.1175371)

Clarke RB, Howell A, Potten CS \& Anderson E 1997 Dissociation between steroid receptor expression and cell proliferation in the human breast. Cancer Research $\mathbf{5 7}$ 4987-4991.

Codru N, Schymura MJ, Negoita S, Rej R \& Carpenter DO 2007 Diabetes in relation to serum levels of polychlorinated biphenyls and chlorinated pesticides in adult Native Americans. Environmental Health Perspectives 115 1442-1447. (doi:10.1289/ehp.10315)

Cohn BA 2011 Developmental and environmental origins of breast cancer: DDT as a case study. Reproductive Toxicology 31 302-311. (doi:10.1016/j. reprotox.2010.10.004)

Cohn BA, Cirillo PM, Wolff MS, Schwingl PJ, Cohen RD, Sholtz RI, Ferrara A, Christianson RE, van den Berg BJ \& Siiteri PK 2003 DDT and DDE exposure in mothers and time to pregnancy in daughters. Lancet 361 2205-2206. (doi:10.1016/S0140-6736(03)13776-2)

Cohn BA, Wolff MS, Cirillo PM \& Sholtz RI 2007 DDT and breast cancer in young women: new data on the significance of age at exposure. Environmental Health Perspectives 115 1406-1414. (doi:10.1289/ehp. 10260)

Cohn BA, Cirillo PM \& Christianson RE 2010 Prenatal DDT exposure and testicular cancer: a nested case-control study. Archives of Environmental \& Occupational Health 65 127-134. (doi:10.1080/19338241003730887)

Cole DC, Wainman B, Sanin LH, Weber JP, Muggah H \& Ibrahim S 2006 Environmental contaminant levels and fecundability among nonsmoking couples. Reproductive Toxicology 22 13-19. (doi:10.1016/j. reprotox.2005.12.001)
Connor K, Ramamoorthy K, Moore M, Mustain M, Chen I, Safe S, Zacharewski T, Gillesby B, Joyeux A \& Balaguer P 1997 Hydroxylated polychlorinated biphenyls (PCBs) as estrogens and antiestrogens: structure-activity relationships. Toxicology and Applied Pharmacology 145 111-123. (doi:10.1006/taap.1997.8169)

Cos P, De Bruyne T, Apers S, Vanden Berghe D, Pieters L \& Vlietinck AJ 2003 Phytoestrogens: recent developments. Planta Medica 69 589-599. (doi:10.1055/s-2003-41122)

Crinnion WJ 2011 Polychlorinated biphenyls: persistent pollutants with immunological, neurological, and endocrinological consequences. Alternative Medicine Review 16 5-13.

Dagdemir A, Durif J, Ngollo M, Bignon YJ \& Bernard-Gallon D 2013 Histone lysine trimethylation or acetylation can be modulated by phytoestrogen, estrogen or anti-HDAC in breast cancer cell lines. Epigenomics 5 51-63. (doi:10.2217/epi.12.74)

Davis J, Khan G, Martin MB \& Hilakivi-Clarke L 2013 Effects of maternal dietary exposure to cadmium during pregnancy on mammary cancer risk among female offspring. Journal of Carcinogenesis $\mathbf{1 2} 11$. (doi:10.4103/1477-3163.114219)

De Assis S \& Hilakivi-Clarke L 2006 Timing of dietary estrogenic exposures and breast cancer risk. Annals of the New York Academy of Sciences 1089 14-35. (doi:10.1196/annals.1386.039)

Demura M \& Bulun SE 2008 CpG dinucleotide methylation of the CYP19 I.3/II promoter modulates cAMP-stimulated aromatase activity. Molecular and Cellular Endocrinology 283 127-132. (doi:10.1016/j.mce. 2007.12.003)

Denissenko MF, Pao A, Tang M \& Pfeifer GP 1996 Preferential formation of benzo[a]pyrene adducts at lung cancer mutational hotspots in P53. Science 274 430-432. (doi:10.1126/science.274.5286.430)

Desaulniers D, Xiao GH, Lian H, Feng YL, Zhu J, Nakai J \& Bowers WJ 2009 Effects of mixtures of polychlorinated biphenyls, methylmercury, and organochlorine pesticides on hepatic DNA methylation in prepubertal female Sprague-Dawley rats. International Journal of Toxicology $\mathbf{2 8}$ 294-307. (doi:10.1177/1091581809337918)

Dewailly E, Ayotte P, Laliberte C, Weber JP, Gingras S \& Nantel AJ 1996 Polychlorinated biphenyl (PCB) and dichlorodiphenyl dichloroethylene (DDE) concentrations in the breast milk of women in Quebec. American Journal of Public Health 86 1241-1246. (doi:10.2105/AJPH.86. 9.1241)

Dhooge W, den Hond E, Koppen G, Bruckers L, Nelen V, van de Mieroop E, Bilau M, Croes K, Baeyens W, Schoeters G et al. 2011 Internal exposure to pollutants and sex hormone levels in Flemish male adolescents in a cross-sectional study: associations and dose-response relationships. Journal of Exposure Science and Environmental Epidemiology 21 106-113. (doi:10.1038/jes.2009.63)

Doherty LF, Bromer JG, Zhou Y, Aldad TS \& Taylor HS 2010 In utero exposure to diethylstilbestrol (DES) or bisphenol-A (BPA) increases EZH2 expression in the mammary gland: an epigenetic mechanism linking endocrine disruptors to breast cancer. Hormones \& Cancer $\mathbf{1}$ 146-155. (doi:10.1007/s12672-010-0015-9)

Dorgan JF, Brock JW, Rothman N, Needham LL, Miller R, Stephenson HE Jr, Schussler N \& Taylor PR 1999 Serum organochlorine pesticides and PCBs and breast cancer risk: results from a prospective analysis (USA). Cancer Causes \& Control 10 1-11. (doi:10.1023/A:1008824 131727)

Doshi T, Mehta SS, Dighe V, Balasinor N \& Vanage G 2011 Hypermethylation of estrogen receptor promoter region in adult testis of rats exposed neonatally to bisphenol A. Toxicology 289 74-82. (doi:10.1016/ j.tox.2011.07.011)

Drenth HJ, Bouwman CA, Seinen W \& Van den Berg M 1998 Effects of some persistent halogenated environmental contaminants on aromatase (CYP19) activity in the human choriocarcinoma cell line JEG-3. Toxicology and Applied Pharmacology 148 50-55. (doi:10.1006/taap. 1997.8307)

Du K, Chu S \& Xu X 2000 Stimulation of MCF-7 cell proliferation by low concentrations of Chinese domestic polychlorinated biphenyls. 
Journal of Toxicology and Environmental Health. Part A 61 201-207. (doi:10.1080/00984100050131341)

Durando M, Kass L, Piva J, Sonnenschein C, Soto AM, Luque EH \& Munoz-de-Toro M 2007 Prenatal bisphenol A exposure induces preneoplastic lesions in the mammary gland in Wistar rats. Environmental Health Perspectives 115 80-86. (doi:10.1289/ehp.9282)

El Sheikh Saad H, Meduri G, Phrakonkham P, Berges R, Vacher S, Djallali M, Auger J, Canivenc-Lavier MC \& Perrot-Applanat M 2011 Abnormal peripubertal development of the rat mammary gland following exposure in utero and during lactation to a mixture of genistein and the food contaminant vinclozolin. Reproductive Toxicology 32 15-25. (doi:10.1016/j.reprotox.2011.03.001)

El Sheikh Saad H, Toullec A, Vacher S, Pocard M, Bieche I \& Perrot-Applanat M 2013 In utero and lactational exposure to vinclozolin and genistein induces genomic changes in the rat mammary gland. Journal of Endocrinology 216 245-263. (doi:10.1530/JOE-12-0395)

Eskenazi B, Chevrier J, Rosas LG, Anderson HA, Bornman MS, Bouwman H, Chen A, Cohn BA, de Jager C, Henshel DS et al. 2009 The Pine River statement: human health consequences of DDT use. Environmental Health Perspectives 117 1359-1367. (doi:10.1289/ehp.11748)

Fang X, Thornton C, Scheffler BE \& Willett KL 2013 Benzo[a]pyrene decreases global and gene specific DNA methylation during Zebrafish development. Environmental Toxicology and Pharmacology 36 40-50. (doi:10.1016/j.etap.2013.02.014)

Fenton SE, Hamm JT, Birnbaum LS \& Youngblood GL 2002 Persistent abnormalities in the rat mammary gland following gestational and lactational exposure to 2,3,7,8-tetrachlorodibenzo-p-dioxin (TCDD). Toxicological Sciences 67 63-74. (doi:10.1093/toxsci/67.1.63)

Fernandez SV, Huang Y, Snider KE, Zhou Y, Pogash TJ \& Russo J 2012 Expression and DNA methylation changes in human breast epithelial cells after bisphenol A exposure. International Journal of Oncology $\mathbf{4 1}$ 369-377. (doi:10.3892/ijo.2012.1444)

Fraga MF, Ballestar E, Villar-Garea A, Boix-Chornet M, Espada J, Schotta G, Bonaldi T, Haydon C, Ropero S, Petrie Ket al. 2005 Loss of acetylation at Lys16 and trimethylation at Lys20 of histone $\mathrm{H} 4$ is a common hallmark of human cancer. Nature Genetics 37 391-400. (doi:10.1038/ng1531)

Frigo DE, Burow ME, Mitchell KA, Chiang TC \& McLachlan JA 2002 DDT and its metabolites alter gene expression in human uterine cell lines through estrogen receptor-independent mechanisms. Environmental Health Perspectives 110 1239-1245. (doi:10.1289/ehp.021101239)

Frigo DE, Basu A, Nierth-Simpson EN, Weldon CB, Dugan CM, Elliott S, Collins-Burow BM, Salvo VA, Zhu Y, Melnik LI et al. 2006 p38 mitogenactivated protein kinase stimulates estrogen-mediated transcription and proliferation through the phosphorylation and potentiation of the p160 coactivator glucocorticoid receptor-interacting protein 1 . Molecular Endocrinology 20 971-983. (doi:10.1210/me.2004-0075)

Furdas SD, Kannan S, Sippl W \& Jung M 2012 Small molecule inhibitors of histone acetyltransferases as epigenetic tools and drug candidates. Archiv der Pharmazie 345 7-21. (doi:10.1002/ardp.201100209)

Gammon MD \& Santella RM 2008 PAH, genetic susceptibility and breast cancer risk: an update from the Long Island Breast Cancer Study Project. European Journal of Cancer 44 636-640. (doi:10.1016/j.ejca. 2008.01.026)

Gammon MD, Santella RM, Neugut AI, Eng SM, Teitelbaum SL, Paykin A, Levin B, Terry MB, Young TL, Wang LW et al. 2002 Environmental toxins and breast cancer on Long Island. I. Polycyclic aromatic hydrocarbon DNA adducts. Cancer Epidemiology, Biomarkers \& Prevention 11 677-685.

Gammon MD, Sagiv SK, Eng SM, Shantakumar S, Gaudet MM, Teitelbaum SL, Britton JA, Terry MB, Wang LW, Wang Q et al. 2004 Polycyclic aromatic hydrocarbon-DNA adducts and breast cancer: a pooled analysis. Archives of Environmental Health 59 640-649. (doi:10.1080/00039890409602948)

Gaudet MM, Gapstur SM, Sun J, Diver WR, Hannan LM \& Thun MJ 2013 Active smoking and breast cancer risk: original cohort data and meta-analysis. Journal of the National Cancer Institute 105 515-525. (doi:10.1093/jnci/djt023)

Gellert RJ 1978 Uterotrophic activity of polychlorinated biphenyls (PCB) and induction of precocious reproductive aging in neonatally treated female rats. Environmental Research 16 123-130. (doi:10.1016/00139351(78)90149-4)

Goldberg AD, Allis CD \& Bernstein E 2007 Epigenetics: a landscape takes shape. Cell 128 635-638. (doi:10.1016/j.cell.2007.02.006)

Golden R \& Kimbrough R 2009 Weight of evidence evaluation of potential human cancer risks from exposure to polychlorinated biphenyls: an update based on studies published since 2003. Critical Reviews in Toxicology 39 299-331. (doi:10.1080/10408440802291521)

Gorlewska-Roberts K, Green B, Fares M, Ambrosone CB \& Kadlubar FF 2002 Carcinogen-DNA adducts in human breast epithelial cells. Environmental and Molecular Mutagenesis 39 184-192. (doi:10.1002/em.10060)

Gray LE Jr, Ostby JS \& Kelce WR 1994 Developmental effects of an environmental antiandrogen: the fungicide vinclozolin alters sex differentiation of the male rat. Toxicology and Applied Pharmacology 129 46-52. (doi:10.1006/taap.1994.1227)

Guerrero-Preston R, Goldman LR, Brebi-Mieville P, Ili-Gangas C, Lebron C, Witter FR, Apelberg BJ, Hernandez-Roystacher M, Jaffe A, Halden RU et al. 2010 Global DNA hypomethylation is associated with in utero exposure to cotinine and perfluorinated alkyl compounds. Epigenetics $\mathbf{5}$ 539-546. (doi:10.4161/epi.5.6.12378)

Guruge KS, Yeung LW, Yamanaka N, Miyazaki S, Lam PK, Giesy JP, Jones PD \& Yamashita N 2006 Gene expression profiles in rat liver treated with perfluorooctanoic acid (PFOA). Toxicological Sciences 89 93-107. (doi:10.1093/toxsci/kfj011)

Hagiwara K, Kosaka N, Yoshioka Y, Takahashi RU, Takeshita F \& Ochiya T 2012 Stilbene derivatives promote Ago2-dependent tumour-suppressive microRNA activity. Scientific Reports 2 314. (doi:10.1038/ srep00314)

Hamouchene H, Arlt VM, Giddings I \& Phillips DH 2011 Influence of cell cycle on responses of MCF-7 cells to benzo[a]pyrene. BMC Genomics 12 333. (doi:10.1186/1471-2164-12-333)

Han EH, Kim HG, Hwang YP, Choi JH, Im JH, Park B, Yang JH, Jeong TC \& Jeong HG 2010 The role of cyclooxygenase-2-dependent signaling via cyclic AMP response element activation on aromatase up-regulation by $o, p^{\prime}$-DDT in human breast cancer cells. Toxicology Letters 198 331-341. (doi:10.1016/j.toxlet.2010.07.015)

Hany J, Lilienthal H, Sarasin A, Roth-Harer A, Fastabend A, Dunemann L, Lichtensteiger W \& Winneke G 1999 Developmental exposure of rats to a reconstituted PCB mixture or aroclor 1254: effects on organ weights, aromatase activity, sex hormone levels, and sweet preference behavior. Toxicology and Applied Pharmacology 158 231-243. (doi:10.1006/taap. 1999.8710)

Hardell L, van Bavel B, Lindstrom G, Bjornfoth H, Orgum P, Carlberg M, Sorensen CS \& Graflund M 2004 Adipose tissue concentrations of $p, p^{\prime}$-DDE and the risk for endometrial cancer. Gynecologic Oncology 95 706-711. (doi:10.1016/j.ygyno.2004.08.022)

Harris RM \& Waring RH 2012 Diethylstilboestrol - a long-term legacy. Maturitas 72 108-112. (doi:10.1016/j.maturitas.2012.03.002)

He YF, Li BZ, Li Z, Liu P, Wang Y, Tang Q, Ding J, Jia Y, Chen Z, Li L et al. 2011 Tet-mediated formation of 5-carboxylcytosine and its excision by TDG in mammalian DNA. Science 333 1303-1307. (doi:10.1126/ science.1210944)

Heneweer M, van den Berg M, de Geest MC, de Jong PC, Bergman A \& Sanderson JT 2005 Inhibition of aromatase activity by methyl sulfonyl PCB metabolites in primary culture of human mammary fibroblasts. Toxicology and Applied Pharmacology 202 50-58. (doi:10.1016/j.taap. 2004.06.006)

Henry ND \& Fair PA 2013 Comparison of in vitro cytotoxicity, estrogenicity and anti-estrogenicity of triclosan, perfluorooctane sulfonate and perfluorooctanoic acid. Journal of Applied Toxicology 33 265-272. (doi:10.1002/jat.1736) 
Herbst AL, Ulfelder H \& Poskanzer DC 1971 Adenocarcinoma of the vagina. Association of maternal stilbestrol therapy with tumor appearance in young women. New England Journal of Medicine 284 878-881. (doi:10.1056/NEJM197104222841604)

Herbstman JB, Tang D, Zhu D, Qu L, Sjodin A, Li Z, Camann D \& Perera FP 2012 Prenatal exposure to polycyclic aromatic hydrocarbons, benzo[a]pyrene-DNA adducts, and genomic DNA methylation in cord blood. Environmental Health Perspectives 120 733-738. (doi:10.1289/ ehp.1104056)

Hermann A, Gowher H \& Jeltsch A 2004 Biochemistry and biology of mammalian DNA methyltransferases. Cellular and Molecular Life Sciences 61 2571-2587. (doi:10.1007/s00018-004-4201-1)

Hilakivi-Clarke L, Cho E \& Clarke R 1998a Maternal genistein exposure mimics the effects of estrogen on mammary gland development in female mouse offspring. Oncology Reports 5 609-616.

Hilakivi-Clarke L, Stoica A, Raygada M \& Martin MB 1998b Consumption of a high-fat diet alters estrogen receptor content, protein kinase $\mathrm{C}$ activity, and mammary gland morphology in virgin and pregnant mice and female offspring. Cancer Research 58 654-660.

Hilakivi-Clarke L, Cho E, Onojafe I, Raygada M \& Clarke R 1999a Maternal exposure to genistein during pregnancy increases carcinogen-induced mammary tumorigenesis in female rat offspring. Oncology Reports 6 1089-1095.

Hilakivi-Clarke L, Onojafe I, Raygada M, Cho E, Skaar T, Russo I \& Clarke R $1999 b$ Prepubertal exposure to zearalenone or genistein reduces mammary tumorigenesis. British Journal of Cancer 80 1682-1688. (doi:10.1038/sj.bjc.6690584)

Hinrichs B, Zahid M, Saeed M, Ali MF, Cavalieri EL \& Rogan EG 2011 Formation of diethylstilbestrol-DNA adducts in human breast epithelial cells and inhibition by resveratrol. Journal of Steroid Biochemistry and Molecular Biology 127 276-281. (doi:10.1016/j.jsbmb. 2011.08.009)

Hirota T, Lipp JJ, Toh BH \& Peters JM 2005 Histone H3 serine 10 phosphorylation by Aurora B causes HP1 dissociation from heterochromatin. Nature 438 1176-1180. (doi:10.1038/nature04254)

Hoover RN, Hyer M, Pfeiffer RM, Adam E, Bond B, Cheville AL, Colton T, Hartge P, Hatch EE, Herbst AL et al. 2011 Adverse health outcomes in women exposed in utero to diethylstilbestrol. New England Journal of Medicine 365 1304-1314. (doi:10.1056/NEJMoa1013961)

Hoyer AP, Grandjean P, Jorgensen T, Brock JW \& Hartvig HB 1998 Organochlorine exposure and risk of breast cancer. Lancet 352 1816-1820. (doi:10.1016/S0140-6736(98)04504-8)

Hsu PY, Deatherage DE, Rodriguez BA, Liyanarachchi S, Weng YI, Zuo T, Liu J, Cheng AS \& Huang TH 2009 Xenoestrogen-induced epigenetic repression of microRNA-9-3 in breast epithelial cells. Cancer Research 69 5936-5945. (doi:10.1158/0008-5472.CAN-08-4914)

Hung T, Wang Y, Lin MF, Koegel AK, Kotake Y, Grant GD, Horlings HM, Shah N, Umbricht C, Wang P et al. 2011 Extensive and coordinated transcription of noncoding RNAs within cell-cycle promoters. Nature Genetics 43 621-629. (doi:10.1038/ng.848)

Innes KE \& Byers TE 1999 Preeclampsia and breast cancer risk. Epidemiology 10 722-732. (doi:10.1097/00001648-199911000-00013)

Irigaray P, Newby JA, Clapp R, Hardell L, Howard V, Montagnier L, Epstein S \& Belpomme D 2007 Lifestyle-related factors and environmental agents causing cancer: an overview. Biomedicine \& Pharmacotherapy 61 640-658. (doi:10.1016/j.biopha.2007.10.006)

Jansen HT, Cooke PS, Porcelli J, Liu TC \& Hansen LG 1993 Estrogenic and antiestrogenic actions of PCBs in the female rat: in vitro and in vivo studies. Reproductive Toxicology 7 237-248. (doi:10.1016/08906238(93)90230-5)

Jawaid K, Crane SR, Nowers JL, Lacey M \& Whitehead SA 2010 Long-term genistein treatment of MCF-7 cells decreases acetylated histone 3 expression and alters growth responses to mitogens and histone deacetylase inhibitors. Journal of Steroid Biochemistry and Molecular Biology 120 164-171. (doi:10.1016/j.jsbmb.2010.04.007)
Jenkins S, Rowell C, Wang J \& Lamartiniere CA 2007 Prenatal TCDD exposure predisposes for mammary cancer in rats. Reproductive Toxicology 23 391-396. (doi:10.1016/j.reprotox.2006.10.004)

Johnson NA, Ho A, Cline JM, Hughes CL, Foster WG \& Davis VL 2012 Accelerated mammary tumor onset in a HER2/Neu mouse model exposed to DDT metabolites locally delivered to the mammary gland. Environmental Health Perspectives 120 1170-1176. (doi:10.1289/ehp. 1104327)

Kahn PC, Gochfeld M, Nygren M, Hansson M, Rappe C, Velez H, Ghent-Guenther T \& Wilson WP 1988 Dioxins and dibenzofurans in blood and adipose tissue of Agent Orange-exposed Vietnam veterans and matched controls. Journal of the American Medical Association 259 1661-1667. (doi:10.1001/jama.1988.03720110023029)

Kao YC, Zhou C, Sherman M, Laughton CA \& Chen S 1998 Molecular basis of the inhibition of human aromatase (estrogen synthetase) by flavone and isoflavone phytoestrogens: a site-directed mutagenesis study. Environmental Health Perspectives 106 85-92. (doi:10.1289/ehp. 9810685)

Karius T, Schnekenburger M, Ghelfi J, Walter J, Dicato M \& Diederich M 2011 Reversible epigenetic fingerprint-mediated glutathione$S$-transferase P1 gene silencing in human leukemia cell lines. Biochemical Pharmacology 81 1329-1342. (doi:10.1016/j.bcp.2011. 03.014)

Karmaus W, Fussman C, Muttineni J \& Zhu X 2004 Backward estimation of exposure to organochlorines using repeated measurements. Environmental Health Perspectives 112 710-716. (doi:10.1289/ehp.6761)

Karmaus W, Osuch JR, Eneli I, Mudd LM, Zhang J, Mikucki D, Haan P \& Davis S 2009 Maternal levels of dichlorodiphenyl-dichloroethylene (DDE) may increase weight and body mass index in adult female offspring. Occupational and Environmental Medicine 66 143-149. (doi:10.1136/oem.2008.041921)

Karmaus W, Osuch JR, Landgraf J, Taffe B, Mikucki D \& Haan P 2011 Prenatal and concurrent exposure to halogenated organic compounds and gene expression of CYP17A1, CYP19A1, and oestrogen receptor $\alpha$ and $\beta$ genes. Occupational and Environmental Medicine 68 430-437. (doi:10.1136/oem.2009.053249)

Katchy A, Pinto C, Jonsson P, Nguyen-Vu T, Pandelova M, Riu A, Schramm KW, Samarov D, Gustafsson JA, Bondesson M et al. 2014 Co-exposure to phytoestrogens and bisphenol A mimic estrogenic effects in an additive manner. Toxicological Sciences 138 21-35. (doi:10.1093/toxsci/kft271)

Kaya H, Hany J, Fastabend A, Roth-Harer A, Winneke G \& Lilienthal H 2002 Effects of maternal exposure to a reconstituted mixture of polychlorinated biphenyls on sex-dependent behaviors and steroid hormone concentrations in rats: dose-response relationship. Toxicology and Applied Pharmacology 178 71-81. (doi:10.1006/taap.2001.9318)

Kelce WR, Monosson E, Gamcsik MP, Laws SC \& Gray LE Jr 1994 Environmental hormone disruptors: evidence that vinclozolin developmental toxicity is mediated by antiandrogenic metabolites. Toxicology and Applied Pharmacology 126 276-285. (doi:10.1006/taap. 1994.1117)

Kelly BC, Gobas FA \& McLachlan MS 2004 Intestinal absorption and biomagnification of organic contaminants in fish, wildlife, and humans. Environmental Toxicology and Chemistry 23 2324-2336. (doi:10.1897/03-545)

Khalil AM, Guttman M, Huarte M, Garber M, Raj A, Rivea Morales D, Thomas K, Presser A, Bernstein BE, van Oudenaarden A et al. 2009 Many human large intergenic noncoding RNAs associate with chromatinmodifying complexes and affect gene expression. PNAS 106 11667-11672. (doi:10.1073/pnas.0904715106)

Kim VN 2006 Small RNAs just got bigger: piwi-interacting RNAs (piRNAs) in mammalian testes. Genes and Development 20 1993-1997. (doi:10.1101/gad.1456106)

Kim KY, Kim DS, Lee SK, Lee IK, Kang JH, Chang YS, Jacobs DR, Steffes M \& Lee DH 2010 Association of low-dose exposure to persistent organic pollutants with global DNA hypomethylation in healthy Koreans. 
Environmental Health Perspectives 118 370-374. (doi:10.1289/ehp. 0901131)

King-Batoon A, Leszczynska JM \& Klein CB 2008 Modulation of gene methylation by genistein or lycopene in breast cancer cells. Environmental and Molecular Mutagenesis 49 36-45. (doi:10.1002/em.20363)

Klotz DM, Beckman BS, Hill SM, McLachlan JA, Walters MR \& Arnold SF 1996 Identification of environmental chemicals with estrogenic activity using a combination of in vitro assays. Environmental Health Perspectives 104 1084-1089. (doi:10.1289/ehp.961041084)

Knower KC, To SQ, Simpson ER \& Clyne CD 2010 Epigenetic mechanisms regulating CYP19 transcription in human breast adipose fibroblasts. Molecular and Cellular Endocrinology 321 123-130. (doi:10.1016/j.mce. 2010.02.035)

Knower KC, To SQ \& Clyne CD 2013 Intracrine oestrogen production and action in breast cancer: an epigenetic focus. Journal of Steroid Biochemistry and Molecular Biology 137 157-164. (doi:10.1016/j.jsbmb. 2013.01.009)

Knox SS, Jackson T, Javins B, Frisbee SJ, Shankar A \& Ducatman AM 2011 Implications of early menopause in women exposed to perfluorocarbons. Journal of Clinical Endocrinology and Metabolism 96 1747-1753. (doi:10.1210/jc.2010-2401)

Korach KS, Sarver P, Chae K, McLachlan JA \& McKinney JD 1988 Estrogen receptor-binding activity of polychlorinated hydroxybiphenyls: conformationally restricted structural probes. Molecular Pharmacology 33 120-126.

Kuiper GG, Lemmen JG, Carlsson B, Corton JC, Safe SH, van der Saag PT, van der Burg B \& Gustafsson JA 1998 Interaction of estrogenic chemicals and phytoestrogens with estrogen receptor $\beta$. Endocrinology 139 4252-4263. (doi:10.1210/endo.139.10.6216)

Kundakovic M, Gudsnuk K, Franks B, Madrid J, Miller RL, Perera FP \& Champagne FA 2013 Sex-specific epigenetic disruption and behavioral changes following low-dose in utero bisphenol A exposure. PNAS 110 9956-9961. (doi:10.1073/pnas.1214056110)

Laden F, Collman G, Iwamoto K, Alberg AJ, Berkowitz GS, Freudenheim JL, Hankinson SE, Helzlsouer KJ, Holford TR, Huang HY et al. 2001 1,1-Dichloro-2,2-bis( $p$-chlorophenyl)ethylene and polychlorinated biphenyls and breast cancer: combined analysis of five U.S. studies. Journal of the National Cancer Institute 93 768-776. (doi:10.1093/jnci/93. 10.768 )

Lagos-Quintana M, Rauhut R, Lendeckel W \& Tuschl T 2001 Identification of novel genes coding for small expressed RNAs. Science 294 853-858. (doi:10.1126/science.1064921)

Lamartiniere CA, Moore JB, Brown NM, Thompson R, Hardin MJ \& Barnes S 1995 Genistein suppresses mammary cancer in rats. Carcinogenesis 16 2833-2840. (doi:10.1093/carcin/16.11.2833)

Lamartiniere CA, Jenkins S, Betancourt AM, Wang J \& Russo J 2011 Exposure to the endocrine disruptor bisphenol A alters susceptibility for mammary cancer. Hormone Molecular Biology and Clinical Investigation 5 45-52. (doi:10.1515/HMBCI.2010.075)

Larson PS, Ungarelli RA, de Las Morenas A, Cupples LA, Rowlings K, Palmer JR \& Rosenberg CL 2006 In utero exposure to diethylstilbestrol (DES) does not increase genomic instability in normal or neoplastic breast epithelium. Cancer 107 2122-2126. (doi:10.1002/cncr.22223)

Le TN \& Johansson A 2001 Impact of chemical warfare with agent orange on women's reproductive lives in Vietnam: a pilot study. Reproductive Health Matters 9 156-164. (doi:10.1016/S0968-8080(01)90102-8)

Lee JJ, Ko E, Cho J, Park HY, Lee JE, Nam SJ, Kim DH \& Cho EY 2012 Methylation and immunoexpression of $\mathrm{p} 16^{\mathrm{INK} 4 \mathrm{a}}$ tumor suppressor gene in primary breast cancer tissue and their quantitative p16 $6^{\text {INK4a }}$ hypermethylation in plasma by real-time PCR. Korean Journal of Pathology 46 554-561. (doi:10.4132/KoreanJPathol.2012.46.6.554)

Lewis BC, Hudgins S, Lewis A, Schorr K, Sommer R, Peterson RE, Flaws JA \& Furth PA 2001 In utero and lactational treatment with 2,3,7,8tetrachlorodibenzo- $p$-dioxin impairs mammary gland differentiation but does not block the response to exogenous estrogen in the postpubertal female rat. Toxicological Sciences 62 46-53. (doi:10.1093/ toxsci/62.1.46)

Li LA 2007 Polychlorinated biphenyl exposure and CYP19 gene regulation in testicular and adrenocortical cell lines. Toxicology In Vitro $\mathbf{2 1}$ 1087-1094. (doi:10.1016/j.tiv.2007.04.002)

Li D, Wang M, Dhingra K \& Hittelman WN 1996 Aromatic DNA adducts in adjacent tissues of breast cancer patients: clues to breast cancer etiology. Cancer Research 56 287-293.

Li S, Hansman R, Newbold R, Davis B, McLachlan JA \& Barrett JC 2003 Neonatal diethylstilbestrol exposure induces persistent elevation of c-fos expression and hypomethylation in its exon-4 in mouse uterus. Molecular Carcinogenesis 38 78-84. (doi:10.1002/mc.10147)

Li B, Carey M \& Workman JL 2007 The role of chromatin during transcription. Cell 128 707-719. (doi:10.1016/j.cell.2007.01.015)

Li Y, Liu L, Andrews LG \& Tollefsbol TO 2009 Genistein depletes telomerase activity through cross-talk between genetic and epigenetic mechanisms. International Journal of Cancer 125 286-296. (doi:10.1002/ ijc.24398)

Li Y, Vandenboom TG II, Wang Z, Kong D, Ali S, Philip PA \& Sarkar FH 2010 miR-146a suppresses invasion of pancreatic cancer cells. Cancer Research 70 1486-1495. (doi:10.1158/0008-5472.CAN-09-2792)

Li F, Wu H, Li L, Li X, Zhao J \& Peijnenburg WJ 2012 Docking and QSAR study on the binding interactions between polycyclic aromatic hydrocarbons and estrogen receptor. Ecotoxicology and Environmental Safety 80 273-279. (doi:10.1016/j.ecoenv.2012.03.009)

Liang J, Zhu H, Li C, Ding Y, Zhou Z \& Wu Q 2012 Neonatal exposure to benzo[a]pyrene decreases the levels of serum testosterone and histone H3K14 acetylation of the StAR promoter in the testes of SD rats. Toxicology 302 285-291. (doi:10.1016/j.tox.2012.08.010)

Lindroth AM, Shultis D, Jasencakova Z, Fuchs J, Johnson L, Schubert D, Patnaik D, Pradhan S, Goodrich J, Schubert I et al. 2004 Dual histone H3 methylation marks at lysines 9 and 27 required for interaction with CHROMOMETHYLASE3. EMBO Journal 23 4286-4296. (doi:10.1038/sj. emboj.7600430)

Lipworth L, Hsieh CC, Wide L, Ekbom A, Yu SZ, Yu GP, Xu B, Hellerstein S, Carlstrom K, Trichopoulos D et al. 1999 Maternal pregnancy hormone levels in an area with a high incidence (Boston, USA) and in an area with a low incidence (Shanghai, China) of breast cancer. British Journal of Cancer 79 7-12. (doi:10.1038/sj.bjc.6690003)

Liu S, Li S \& Du Y 2010 Polychlorinated biphenyls (PCBs) enhance metastatic properties of breast cancer cells by activating Rho-associated kinase (ROCK). PLOS ONE 5 e11272. (doi:10.1371/journal.pone. 0011272)

Lopez-Espinosa MJ, Fletcher T, Armstrong B, Genser B, Dhatariya K, Mondal D, Ducatman A \& Leonardi G 2011 Association of perfluorooctanoic acid (PFOA) and perfluorooctane sulfonate (PFOS) with age of puberty among children living near a chemical plant. Environmental Science \& Technology 45 8160-8166. (doi:10.1021/es1038694)

Lou I, Wambaugh JF, Lau C, Hanson RG, Lindstrom AB, Strynar MJ, Zehr RD, Setzer RW \& Barton HA 2009 Modeling single and repeated dose pharmacokinetics of PFOA in mice. Toxicological Sciences $\mathbf{1 0 7}$ 331-341. (doi:10.1093/toxsci/kfn234)

Luijten M, Thomsen AR, van den Berg JA, Wester PW, Verhoef A, Nagelkerke NJ, Adlercreutz H, van Kranen HJ, Piersma AH, Sorensen IK et al. 2004 Effects of soy-derived isoflavones and a high-fat diet on spontaneous mammary tumor development in Tg.NK (MMTV/c-neu) mice. Nutrition and Cancer 50 46-54. (doi:10.1207/ s15327914nc5001_7)

Luo J, Margolis KL, Wactawski-Wende J, Horn K, Messina C, Stefanick ML, Tindle HA, Tong E \& Rohan TE 2011 Association of active and passive smoking with risk of breast cancer among postmenopausal women: a prospective cohort study. BMJ 342 d1016. (doi:10.1136/bmj.d1016)

Macon MB \& Fenton SE 2013 Endocrine disruptors and the breast: early life effects and later life disease. Journal of Mammary Gland Biology \& Neoplasia 18 43-61. (doi:10.1007/s10911-013-9275-7) 
Macon MB, Villanueva LR, Tatum-Gibbs K, Zehr RD, Strynar MJ, Stanko JP, White SS, Helfant L \& Fenton SE 2011 Prenatal perfluorooctanoic acid exposure in CD-1 mice: low-dose developmental effects and internal dosimetry. Toxicological Sciences 122 134-145. (doi:10.1093/toxsci/ kfr076)

Maggiolini M, Bonofiglio D, Marsico S, Panno ML, Cenni B, Picard D \& Ando S 2001 Estrogen receptor $\alpha$ mediates the proliferative but not the cytotoxic dose-dependent effects of two major phytoestrogens on human breast cancer cells. Molecular Pharmacology 60 595-602.

Manikkam M, Tracey R, Guerrero-Bosagna C \& Skinner MK 2012 Dioxin (TCDD) induces epigenetic transgenerational inheritance of adult onset disease and sperm epimutations. PLoS ONE 7 e46249. (doi:10.1371/journal.pone.0046249)

Manjer J, Malina J, Berglund G, Bondeson L, Garne JP \& Janzon L 2001 Smoking associated with hormone receptor negative breast cancer. International Journal of Cancer 91 580-584. (doi:10.1002/10970215(200002)9999:9999 <::AID-IJC1091> 3.0.CO;2-V)

Manuwald U, Velasco Garrido M, Berger J, Manz A \& Baur X 2012 Mortality study of chemical workers exposed to dioxins: follow-up 23 years after chemical plant closure. Occupational and Environmental Medicine 69 636-642. (doi:10.1136/oemed-2012-100682)

Markey CM, Luque EH, Munoz De Toro M, Sonnenschein C \& Soto AM 2001 In utero exposure to bisphenol A alters the development and tissue organization of the mouse mammary gland. Biology of Reproduction $\mathbf{6 5}$ 1215-1223.

Mastrangelo G, Fadda E \& Marzia V 1996 Polycyclic aromatic hydrocarbons and cancer in man. Environmental Health Perspectives 104 1166-1170. (doi:10.1289/ehp.961041166)

Mathers JC, Strathdee G \& Relton CL 2010 Induction of epigenetic alterations by dietary and other environmental factors. Advances in Genetics 71 3-39. (doi:10.1016/B978-0-12-380864-6.00001-8)

McGlynn KA, Quraishi SM, Graubard BI, Weber JP, Rubertone MV \& Erickson RL 2008 Persistent organochlorine pesticides and risk of testicular germ cell tumors. Journal of the National Cancer Institute 100 663-671. (doi:10.1093/jnci/djn101)

McKeigue PM, Marmot MG, Adelstein AM, Hunt SP, Shipley MJ, Butler SM, Riemersma RA \& Turner PR 1985 Diet and risk factors for coronary heart disease in Asians in northwest London. Lancet 2 1086-1090. (doi:10.1016/S0140-6736(85)90684-1)

Miller ME, Holloway AC \& Foster WG 2005 Benzo-[a]-pyrene increases invasion in MDA-MB-231 breast cancer cells via increased COX-II expression and prostaglandin $\mathrm{E}_{2}\left(\mathrm{PGE}_{2}\right)$ output. Clinical \& Experimental Metastasis 22 149-156. (doi:10.1007/s10585-005-6536-x)

Millikan R, DeVoto E, Duell EJ, Tse CK, Savitz DA, Beach J, Edmiston S, Jackson S \& Newman B 2000 Dichlorodiphenyldichloroethene, polychlorinated biphenyls, and breast cancer among African-American and white women in North Carolina. Cancer Epidemiology, Biomarkers \& Prevention 9 1233-1240.

Mlynarcikova A, Macho L \& Fickova M 2013 Bisphenol A alone or in combination with estradiol modulates cell cycle- and apoptosis-related proteins and genes in MCF7 cells. Endocrine Regulations 47 189-199. (doi:10.4149/endo_2013_04_189)

Moffat ID, Boutros PC, Celius T, Linden J, Pohjanvirta R \& Okey AB 2007 microRNAs in adult rodent liver are refractory to dioxin treatment. Toxicological Sciences 99 470-487. (doi:10.1093/toxsci/kfm189)

Monosson E, Kelce WR, Lambright C, Ostby J \& Gray LE Jr 1999 Peripubertal exposure to the antiandrogenic fungicide, vinclozolin, delays puberty, inhibits the development of androgen-dependent tissues, and alters androgen receptor function in the male rat. Toxicology and Industrial Health 15 65-79. (doi:10.1177/074823379901500107)

Moral R, Wang R, Russo IH, Lamartiniere CA, Pereira J \& Russo J 2008 Effect of prenatal exposure to the endocrine disruptor bisphenol $\mathrm{A}$ on mammary gland morphology and gene expression signature. Journal of Endocrinology 196 101-112. (doi:10.1677/JOE-07-0056)

Morgan HD, Dean W, Coker HA, Reik W \& Petersen-Mahrt SK 2004 Activation-induced cytidine deaminase deaminates 5-methylcytosine in DNA and is expressed in pluripotent tissues: implications for epigenetic reprogramming. Journal of Biological Chemistry 279 52353-52360. (doi:10.1074/jbc.M407695200)

Morito K, Aomori T, Hirose T, Kinjo J, Hasegawa J, Ogawa S, Inoue S, Muramatsu M \& Masamune Y 2002 Interaction of phytoestrogens with estrogen receptors $\alpha$ and $\beta$ (II). Biological \& Pharmaceutical Bulletin 25 48-52. (doi:10.1248/bpb.25.48)

Moysich KB, Ambrosone CB, Vena JE, Shields PG, Mendola P, Kostyniak P, Greizerstein H, Graham S, Marshall JR, Schisterman EF et al. 1998 Environmental organochlorine exposure and postmenopausal breast cancer risk. Cancer Epidemiology, Biomarkers \& Prevention 7 181-188.

Munoz-de-Toro M, Markey CM, Wadia PR, Luque EH, Rubin BS, Sonnenschein C \& Soto AM 2005 Perinatal exposure to bisphenol-A alters peripubertal mammary gland development in mice. Endocrinology 146 4138-4147. (doi:10.1210/en.2005-0340)

Nakayama M, Gonzalgo ML, Yegnasubramanian S, Lin X, De Marzo AM \& Nelson WG 2004 GSTP1 CpG island hypermethylation as a molecular biomarker for prostate cancer. Journal of Cellular Biochemistry 91 540-552. (doi:10.1002/jcb.10740)

Nan X, Ng HH, Johnson CA, Laherty CD, Turner BM, Eisenman RN \& Bird A 1998 Transcriptional repression by the methyl-CpG-binding protein MeCP2 involves a histone deacetylase complex. Nature 393 386-389. (doi:10.1038/30764)

Ociepa-Zawal M, Rubis B, Wawrzynczak D, Wachowiak R \& Trzeciak WH 2010 Accumulation of environmental estrogens in adipose tissue of breast cancer patients. Journal of Environmental Science and Health Part A, Toxic/hazardous Substances \& Environmental Engineering $\mathbf{4 5}$ 305-312. (doi:10.1080/10934520903468038)

Oenga GN, Spink DC \& Carpenter DO 2004 TCDD and PCBs inhibit breast cancer cell proliferation in vitro. Toxicology In Vitro 18 811-819. (doi:10. 1016/j.tiv.2004.04.004)

Ogura I, Masunaga S \& Nakanishi J 2004 Quantitative source identification of dioxin-like PCBs in Yokohama, Japan, by temperature dependence of their atmospheric concentrations. Environmental Science \& Technology 38 3279-3285. (doi:10.1021/es0354622)

Okamura K, Chung WJ, Ruby JG, Guo H, Bartel DP \& Lai EC 2008 The Drosophila hairpin RNA pathway generates endogenous short interfering RNAs. Nature 453 803-806. (doi:10.1038/nature07015)

Ooi SK, O'Donnell AH \& Bestor TH 2009 Mammalian cytosine methylation at a glance. Journal of Cell Science $\mathbf{1 2 2} 2787-2791$. (doi:10.1242/jcs. 015123)

Paluszczak J, Krajka-Kuzniak V \& Baer-Dubowska W 2010 The effect of dietary polyphenols on the epigenetic regulation of gene expression in MCF7 breast cancer cells. Toxicology Letters 192 119-125. (doi:10.1016/ j.toxlet.2009.10.010)

Papoutsis AJ, Lamore SD, Wondrak GT, Selmin OI \& Romagnolo DF 2010 Resveratrol prevents epigenetic silencing of BRCA- 1 by the aromatic hydrocarbon receptor in human breast cancer cells. Journal of Nutrition 140 1607-1614. (doi:10.3945/jn.110.123422)

Papoutsis AJ, Selmin OI, Borg JL \& Romagnolo DF 2013 Gestational exposure to the AhR agonist 2,3,7,8-tetrachlorodibenzo-p-dioxin induces BRCA-1 promoter hypermethylation and reduces BRCA-1 expression in mammary tissue of rat offspring: preventive effects of resveratrol. Molecular Carcinogenesis. (doi:10.1002/mc.22095)

Pei RJ, Sato M, Yuri T, Danbara N, Nikaido Y \& Tsubura A 2003 Effect of prenatal and prepubertal genistein exposure on $N$-methyl- $N$-nitrosourea-induced mammary tumorigenesis in female Sprague-Dawley rats. In Vivo 17 349-357.

Perera F, Tang WY, Herbstman J, Tang D, Levin L, Miller R \& Ho SM 2009 Relation of DNA methylation of $5^{\prime}$-CpG island of ACSL3 to transplacental exposure to airborne polycyclic aromatic hydrocarbons and childhood asthma. PLoS ONE 4 e4488. (doi:10.1371/journal.pone. 0004488)

Petesch SJ \& Lis JT 2012 Activator-induced spread of poly(ADP-ribose) polymerase promotes nucleosome loss at Hsp70. Molecular Cell 45 64-74. (doi:10.1016/j.molcel.2011.11.015) 
Petreas M, Nelson D, Brown FR, Goldberg D, Hurley S \& Reynolds P 2011 High concentrations of polybrominated diphenylethers (PBDEs) in breast adipose tissue of California women. Environment International 37 190-197. (doi:10.1016/j.envint.2010.09.001)

Pineda MD, White E, Kristal AR \& Taylor V 2001 Asian breast cancer survival in the US: a comparison between Asian immigrants, US-born Asian Americans and Caucasians. International Journal of Epidemiology 30 976-982. (doi:10.1093/ije/30.5.976)

Porta M, Bosch de Basea M, Benavides FG, Lopez T, Fernandez E, Marco E, Alguacil J, Grimalt JO \& Puigdomenech E 2008 Differences in serum concentrations of organochlorine compounds by occupational social class in pancreatic cancer. Environmental Research 108 370-379. (doi:10. 1016/j.envres.2008.06.010)

Pratt MM, John K, MacLean AB, Afework S, Phillips DH \& Poirier MC 2011 Polycyclic aromatic hydrocarbon (PAH) exposure and DNA adduct semi-quantitation in archived human tissues. International Journal of Environmental Research and Public Health 8 2675-2691. (doi:10.3390/ ijerph8072675)

Ptak A, Mazur K \& Gregoraszczuk EL 2011 Comparison of combinatory effects of PCBs $(118,138,153$ and 180) with 17ß-estradiol on proliferation and apoptosis in MCF-7 breast cancer cells. Toxicology and Industrial Health 27 315-321. (doi:10.1177/0748233710387003)

Pupo M, Pisano A, Lappano R, Santolla MF, De Francesco EM, Abonante S, Rosano C \& Maggiolini M 2012 Bisphenol A induces gene expression changes and proliferative effects through GPER in breast cancer cells and cancer-associated fibroblasts. Environmental Health Perspectives 120 1177-1182. (doi:10.1289/ehp.1104526)

Qin W, Zhu W, Shi H, Hewett JE, Ruhlen RL, MacDonald RS, Rottinghaus GE, Chen YC \& Sauter ER 2009 Soy isoflavones have an antiestrogenic effect and alter mammary promoter hypermethylation in healthy premenopausal women. Nutrition and Cancer 61 238-244. (doi:10.1080/01635580802404196)

Qin XY, Zaha H, Nagano R, Yoshinaga J, Yonemoto J \& Sone H 2011 Xenoestrogens down-regulate aryl-hydrocarbon receptor nuclear translocator 2 mRNA expression in human breast cancer cells via an estrogen receptor $\alpha$-dependent mechanism. Toxicology Letters 206 152-157. (doi:10.1016/j.toxlet.2011.07.007)

Qin XY, Fukuda T, Yang L, Zaha H, Akanuma H, Zeng Q, Yoshinaga J \& Sone H 2012 Effects of bisphenol A exposure on the proliferation and senescence of normal human mammary epithelial cells. Cancer Biology \& Therapy 13 296-306. (doi:10.4161/cbt.18942)

Quignot N, Arnaud M, Robidel F, Lecomte A, Tournier M, Cren-Olive C, Barouki R \& Lemazurier E 2012 Characterization of endocrinedisrupting chemicals based on hormonal balance disruption in male and female adult rats. Reproductive Toxicology 33 339-352. (doi:10.1016/ j.reprotox.2012.01.004)

Qureshi IA \& Mehler MF 2012 Emerging roles of non-coding RNAs in brain evolution, development, plasticity and disease. Nature Reviews. Neuroscience 13 528-541. (doi:10.1038/nrn3234)

Rackham O, Shearwood AM, Mercer TR, Davies SM, Mattick JS \& Filipovska A 2011 Long noncoding RNAs are generated from the mitochondrial genome and regulated by nuclear-encoded proteins RNA 17 2085-2093. (doi:10.1261/rna.029405.111)

Radice S, Chiesara E, Fucile S \& Marabini L 2008 Different effects of PCB101, PCB118, PCB138 and PCB153 alone or mixed in MCF-7 breast cancer cells. Food and Chemical Toxicology 46 2561-2567. (doi:10.1016/j.fct. 2008.04.012)

Ray SS \& Swanson HI 2004 Dioxin-induced immortalization of normal human keratinocytes and silencing of p53 and p16 $6^{\mathrm{INK} 4 \mathrm{a}}$. Journal of Biological Chemistry 279 27187-27193. (doi:10.1074/jbc.M402771200)

Reichert N, Choukrallah MA \& Matthias P 2012 Multiple roles of class I HDACs in proliferation, differentiation, and development. Cellular and Molecular Life Sciences 69 2173-2187. (doi:10.1007/s00018-012-0921-9)

Robison AK, Sirbasku DA \& Stancel GM 1985 DDT supports the growth of an estrogen-responsive tumor. Toxicology Letters 27 109-113. (doi:10.1016/0378-4274(85)90127-4)
Rogan WJ 1996 Pollutants in breast milk. Archives of Pediatrics \& Adolescent Medicine 150 981-990. (doi:10.1001/archpedi.1996.02170340095018) van Roon EH, de Miranda NF, van Nieuwenhuizen MP, de Meijer EJ, van Puijenbroek M, Yan PS, Huang TH, van Wezel T, Morreau H \& Boer JM 2011 Tumour-specific methylation of PTPRG intron 1 locus in sporadic and Lynch syndrome colorectal cancer. European Journal of Human Genetics 19 307-312. (doi:10.1038/ejhg.2010.187)

Rosen MB, Thibodeaux JR, Wood CR, Zehr RD, Schmid JE \& Lau C 2007 Gene expression profiling in the lung and liver of PFOA-exposed mouse fetuses. Toxicology 239 15-33. (doi:10.1016/j.tox.2007.06.095)

Rosen MB, Abbott BD, Wolf DC, Corton JC, Wood CR, Schmid JE, Das KP, Zehr RD, Blair ET \& Lau C 2008a Gene profiling in the livers of wild-type and PPAR $\alpha$-null mice exposed to perfluorooctanoic acid. Toxicologic Pathology 36 592-607. (doi:10.1177/0192623308318208)

Rosen MB, Lee JS, Ren H, Vallanat B, Liu J, Waalkes MP, Abbott BD, Lau C \& Corton JC $2008 b$ Toxicogenomic dissection of the perfluorooctanoic acid transcript profile in mouse liver: evidence for the involvement of nuclear receptors PPAR $\alpha$ and CAR. Toxicological Sciences 103 46-56. (doi:10.1093/toxsci/kfn025)

Rothman N, Correa-Villasenor A, Ford DP, Poirier MC, Haas R, Hansen JA, O'Toole T \& Strickland PT 1993a Contribution of occupation and diet to white blood cell polycyclic aromatic hydrocarbon-DNA adducts in wildland firefighters. Cancer Epidemiology, Biomarkers \& Prevention 2 341-347.

Rothman N, Poirier MC, Haas RA, Correa-Villasenor A, Ford P, Hansen JA O'Toole T \& Strickland PT 1993b Association of PAH-DNA adducts in peripheral white blood cells with dietary exposure to polyaromatic hydrocarbons. Environmental Health Perspectives 99 265-267. (doi:10. 1289/ehp.9399265)

Rothschild TC, Boylan ES, Calhoon RE \& Vonderhaar BK 1987 Transplacental effects of diethylstilbestrol on mammary development and tumorigenesis in female ACI rats. Cancer Research 47 4508-4516.

Rundle A, Tang D, Hibshoosh H, Estabrook A, Schnabel F, Cao W, Grumet S $\&$ Perera FP 2000 The relationship between genetic damage from polycyclic aromatic hydrocarbons in breast tissue and breast cancer. Carcinogenesis 21 1281-1289. (doi:10.1093/carcin/21.7.1281)

Rusiecki JA, Baccarelli A, Bollati V, Tarantini L, Moore LE \& BonefeldJorgensen EC 2008 Global DNA hypomethylation is associated with high serum-persistent organic pollutants in Greenlandic Inuit. Environmental Health Perspectives 116 1547-1552. (doi:10.1289/ehp.11338)

Sadikovic B, Andrews J \& Rodenhiser DI 2007 DNA methylation analysis using CpG microarrays is impaired in benzopyrene exposed cells. Toxicology and Applied Pharmacology 225 300-309. (doi:10.1016/j.taap. 2007.08.013)

Sadikovic B, Andrews J, Carter D, Robinson J \& Rodenhiser DI 2008 Genome-wide H3K9 histone acetylation profiles are altered in benzopyrene-treated MCF7 breast cancer cells. Journal of Biological Chemistry 283 4051-4060. (doi:10.1074/jbc.M707506200)

Safe SH \& Zacharewski T 1997 Organochlorine exposure and risk for breast cancer. Progress in Clinical and Biological Research 396 133-145. (doi:10.1016/S0140-6736(98)04504-8)

Sagiv SK, Gaudet MM, Eng SM, Abrahamson PE, Shantakumar S, Teitelbaum SL, Bell P, Thomas JA, Neugut AI, Santella RM et al. 2009 Polycyclic aromatic hydrocarbon-DNA adducts and survival among women with breast cancer. Environmental Research 109 287-291. (doi:10.1016/j.envres.2008.11.005)

Sakabe K, Wang Z \& Hart GW $2010 \beta$-N-acetylglucosamine (O-GlcNAc) is part of the histone code. PNAS 107 19915-19920. (doi:10.1073/pnas. 1009023107)

Salay E \& Garabrant D 2009 Polychlorinated biphenyls and thyroid hormones in adults: a systematic review appraisal of epidemiological studies. Chemosphere 74 1413-1419. (doi:10.1016/j.chemosphere.2008. 11.031)

Sandovici I, Smith NH, Nitert MD, Ackers-Johnson M, Uribe-Lewis S, Ito Y, Jones RH, Marquez VE, Cairns W, Tadayyon M et al. 2011 Maternal diet and aging alter the epigenetic control of a promoter-enhancer 
interaction at the $H N F 4 a$ gene in rat pancreatic islets. PNAS $\mathbf{1 0 8}$ 5449-5454. (doi:10.1073/pnas.1019007108)

Santodonato J 1997 Review of the estrogenic and antiestrogenic activity of polycyclic aromatic hydrocarbons: relationship to carcinogenicity. Chemosphere 34 835-848. (doi:10.1016/S0045-6535(97)00012-X)

Sato K, Fukata H, Kogo Y, Ohgane J, Shiota K \& Mori C 2009 Neonatal exposure to diethylstilbestrol alters expression of DNA methyltransferases and methylation of genomic DNA in the mouse uterus. Endocrine Journal 56 131-139. (doi:10.1507/endocrj.K08E-239)

Savitz DA, Stein CR, Bartell SM, Elston B, Gong J, Shin HM \& Wellenius GA 2012 Perfluorooctanoic acid exposure and pregnancy outcome in a highly exposed community. Epidemiology 23 386-392. (doi:10.1097/ EDE.0b013e31824cb93b)

Seals R, Bartell SM \& Steenland K 2011 Accumulation and clearance of perfluorooctanoic acid (PFOA) in current and former residents of an exposed community. Environmental Health Perspectives 119 119-124. (doi:10.1289/ehp.1002346)

Sengupta S, Obiorah I, Maximov P, Curpan R \& Jordan V 2013 Molecular mechanism of action of bisphenol and bisphenol A mediated by oestrogen receptor $\alpha$ in growth and apoptosis of breast cancer cells. British Journal of Pharmacology 169 167-178. (doi:10.1111/bph.12122)

Shenker NS, Polidoro S, van Veldhoven K, Sacerdote C, Ricceri F, Birrell MA, Belvisi MG, Brown R, Vineis P \& Flanagan JM 2013 Epigenome-wide association study in the European Prospective Investigation into Cancer and Nutrition (EPIC-Turin) identifies novel genetic loci associated with smoking. Human Molecular Genetics 22 843-851. (doi:10.1093/hmg/dds488)

Sheth S, Jajoo S, Kaur T, Mukherjea D, Sheehan K, Rybak LP \& Ramkumar V 2012 Resveratrol reduces prostate cancer growth and metastasis by inhibiting the Akt/MicroRNA-21 pathway. PLOS ONE 7 e51655. (doi:10. 1371/journal.pone.0051655)

Shutoh Y, Takeda M, Ohtsuka R, Haishima A, Yamaguchi S, Fujie H, Komatsu Y, Maita K \& Harada T 2009 Low dose effects of dichlorodiphenyltrichloroethane (DDT) on gene transcription and DNA methylation in the hypothalamus of young male rats: implication of hormesis-like effects. Journal of Toxicological Sciences 34 469-482. (doi:10.2131/jts.34.469)

Sieli PT, Jasarevic E, Warzak DA, Mao J, Ellersieck MR, Liao C, Kannan K, Collet SH, Toutain PL, Vom Saal FS et al. 2011 Comparison of serum bisphenol A concentrations in mice exposed to bisphenol A through the diet versus oral bolus exposure. Environmental Health Perspectives 119 1260-1265. (doi:10.1289/ehp.1003385)

Sievers CK, Shanle EK, Bradfield CA \& Xu W 2013 Differential action of monohydroxylated polycyclic aromatic hydrocarbons with estrogen receptors $\alpha$ and $\beta$. Toxicological Sciences 132 359-367. (doi:10.1093/ toxsci/kfs287)

Silva JM, Perez DS, Pritchett JR, Halling ML, Tang H \& Smith DI 2010 Identification of long stress-induced non-coding transcripts that have altered expression in cancer. Genomics 95 355-362. (doi:10.1016/j. ygeno.2010.02.009)

Simon R, Gomez Ruiz JA, von Holst C, Wenzl T \& Anklam E 2008 Results of a European inter-laboratory comparison study on the determination of EU priority polycyclic aromatic hydrocarbons (PAHs) in edible vegetable oils. Analytical and Bioanalytical Chemistry 391 1397-1408. (doi:10.1007/s00216-007-1771-4)

Simpson ER, Zhao Y, Agarwal VR, Michael MD, Bulun SE, Hinshelwood MM, Graham-Lorence S, Sun T, Fisher CR, Qin K et al. 1997 Aromatase expression in health and disease. Recent Progress in Hormone Research 52 185-213 discussion 213-184.

Soto AM, Brisken C, Schaeberle C \& Sonnenschein C 2013 Does cancer start in the womb? altered mammary gland development and predisposition to breast cancer due to in utero exposure to endocrine disruptors. Journal of Mammary Gland Biology \& Neoplasia 18 199-208. (doi:10.1007/s10911-013-9293-5)

Spink DC, Wu SJ, Spink BC, Hussain MM, Vakharia DD, Pentecost BT \& Kaminsky LS 2008 Induction of CYP1A1 and CYP1B1 by benzo(k)fluoranthene and benzo[a]pyrene in T-47D human breast cancer cells: roles of PAH interactions and PAH metabolites. Toxicology and Applied Pharmacology 226 213-224. (doi:10.1016/j.taap.2007. 08.024)

Su Y, Eason RR, Geng Y, Till SR, Badger TM \& Simmen RC 2007 In utero exposure to maternal diets containing soy protein isolate, but not genistein alone, protects young adult rat offspring from NMU-induced mammary tumorigenesis. Carcinogenesis 28 1046-1051. (doi:10.1093/ carcin/bgl240)

Tahiliani M, Koh KP, Shen Y, Pastor WA, Bandukwala H, Brudno Y, Agarwal S, Iyer LM, Liu DR, Aravind L et al. 2009 Conversion of 5-methylcytosine to 5-hydroxymethylcytosine in mammalian DNA by MLL partner TET1. Science 324 930-935. (doi:10.1126/science. 1170116)

Takayanagi S, Tokunaga T, Liu X, Okada H, Matsushima A \& Shimohigashi Y 2006 Endocrine disruptor bisphenol A strongly binds to human estrogen-related receptor $\gamma(\operatorname{ERR} \gamma)$ with high constitutive activity. Toxicology Letters 167 95-105. (doi:10.1016/j.toxlet.2006. 08.012)

Tang WY, Newbold R, Mardilovich K, Jefferson W, Cheng RY, Medvedovic M \& Ho SM 2008 Persistent hypomethylation in the promoter of nucleosomal binding protein 1 (Nsbp1) correlates with overexpression of Nsbp1 in mouse uteri neonatally exposed to diethylstilbestrol or genistein. Endocrinology 149 5922-5931. (doi:10.1210/en.2008-0682)

Tang WY, Levin L, Talaska G, Cheung YY, Herbstman J, Tang D, Miller RL, Perera F \& Ho SM 2012a Maternal exposure to polycyclic aromatic hydrocarbons and $5^{\prime}$-CpG methylation of interferon- $\gamma$ in cord white blood cells. Environmental Health Perspectives 120 1195-1200. (doi:10.1289/ehp.1103744)

Tang WY, Morey LM, Cheung YY, Birch L, Prins GS \& Ho SM $2012 b$ Neonatal exposure to estradiol/bisphenol A alters promoter methylation and expression of Nsbp1 and Hpcal1 genes and transcriptional programs of $D n m t 3 a / b$ and $M b d 2 / 4$ in the rat prostate gland throughout life. Endocrinology 153 42-55. (doi:10.1210/en.2011-1308)

Tharp AP, Maffini MV, Hunt PA, VandeVoort CA, Sonnenschein C \& Soto AM 2012 Bisphenol A alters the development of the rhesus monkey mammary gland. PNAS 109 8190-8195. (doi:10.1073/pnas. 1120488109)

Thompson PA, DeMarini DM, Kadlubar FF, McClure GY, Brooks LR, Green BL, Fares MY, Stone A, Josephy PD \& Ambrosone CB 2002 Evidence for the presence of mutagenic arylamines in human breast milk and DNA adducts in exfoliated breast ductal epithelial cells. Environmental and Molecular Mutagenesis 39 134-142. (doi:10.1002/ em.10067)

Tian M, Peng S, Martin FL, Zhang J, Liu L, Wang Z, Dong S \& Shen H 2012 Perfluorooctanoic acid induces gene promoter hypermethylation of glutathione-S-transferase Pi in human liver L02 cells. Toxicology 296 48-55. (doi:10.1016/j.tox.2012.03.003)

Tilghman SL, Bratton MR, Segar HC, Martin EC, Rhodes LV, Li M, McLachlan JA, Wiese TE, Nephew KP \& Burow ME 2012 Endocrine disruptor regulation of microRNA expression in breast carcinoma cells PLOS ONE 7 e32754. (doi:10.1371/journal.pone.0032754)

Tretyakova N, Matter B, Jones R \& Shallop A 2002 Formation of benzo[a]pyrene diol epoxide-DNA adducts at specific guanines within $K$-ras and $p 53$ gene sequences: stable isotope-labeling mass spectrometry approach. Biochemistry 41 9535-9544. (doi:10.1021/ bi025540i)

Trock BJ, Hilakivi-Clarke L \& Clarke R 2006 Meta-analysis of soy intake and breast cancer risk. Journal of the National Cancer Institute 98 459-471. (doi:10.1093/jnci/dji102)

Troisi R, Hatch EE, Titus-Ernstoff L, Hyer M, Palmer JR, Robboy SJ, Strohsnitter WC, Kaufman R, Herbst AL \& Hoover RN 2007 Cancer risk in women prenatally exposed to diethylstilbestrol. International Journal of Cancer 121 356-360. (doi:10.1002/ijc.22631) 
Tullner WW 1961 Uterotrophic action of the insecticide methoxychlor. Science 133 647. (doi:10.1126/science.133.3453.647)

Vandenberg LN, Maffini MV, Schaeberle CM, Ucci AA, Sonnenschein C, Rubin BS \& Soto AM 2008 Perinatal exposure to the xenoestrogen bisphenol-A induces mammary intraductal hyperplasias in adult CD-1 mice. Reproductive Toxicology 26 210-219. (doi:10.1016/j.reprotox. 2008.09.015)

Venkatesha VA, Kalen AL, Sarsour EH \& Goswami PC 2010 PCB-153 exposure coordinates cell cycle progression and cellular metabolism in human mammary epithelial cells. Toxicology Letters 196 110-116. (doi:10.1016/j.toxlet.2010.04.005)

Verner MA, Bachelet D, McDougall R, Charbonneau M, Guenel P \& Haddad S 2011 A case study addressing the reliability of polychlorinated biphenyl levels measured at the time of breast cancer diagnosis in representing early-life exposure. Cancer Epidemiology, Biomarkers \& Prevention 20 281-286. (doi:10.1158/1055-9965.EPI-10-0992)

Vire E, Brenner C, Deplus R, Blanchon L, Fraga M, Didelot C, Morey L, Van Eynde A, Bernard D, Vanderwinden JM et al. 2006 The Polycomb group protein EZH2 directly controls DNA methylation. Nature $\mathbf{4 3 9}$ 871-874. (doi:10.1038/nature04431)

Volkel W, Colnot T, Csanady GA, Filser JG \& Dekant W 2002 Metabolism and kinetics of bisphenol A in humans at low doses following oral administration. Chemical Research in Toxicology 15 1281-1287. (doi:10.1021/tx025548t)

Walker BE 1990 Tumors in female offspring of control and diethylstilbestrol-exposed mice fed high-fat diets. Journal of the National Cancer Institute 82 50-54. (doi:10.1093/jnci/82.1.50)

Walker CL \& Ho SM 2012 Developmental reprogramming of cancer susceptibility. Nature Reviews. Cancer 12 479-486. (doi:10.1038/ $\operatorname{nrc} 3220)$

Wan YJ, Li YY, Xia W, Chen J, Lv ZQ, Zeng HC, Zhang L, Yang WJ, Chen T, Lin $Y$ et al. 2010 Alterations in tumor biomarker GSTP gene methylation patterns induced by prenatal exposure to PFOS. Toxicology 274 57-64. (doi:10.1016/j.tox.2010.05.006)

Wapinski O \& Chang HY 2011 Long noncoding RNAs and human disease. Trends in Cell Biology 21 354-361. (doi:10.1016/j.tcb.2011.04.001)

Warner M, Mocarelli P, Samuels S, Needham L, Brambilla P \& Eskenazi B 2011 Dioxin exposure and cancer risk in the Seveso Women's Health Study. Environmental Health Perspectives 119 1700-1705. (doi:10.1289/ ehp.1103720)

Warner J, Osuch JR, Karmaus W, Landgraf JR, Taffe B, O'Keefe M, Mikucki D \& Haan P 2012 Common classification schemes for PCB congeners and the gene expression of CYP17, CYP19, ESR1 and ESR2. Science of the Total Environment 414 81-89. (doi:10.1016/j.scitotenv.2011.10.044)

Weber Lozada K \& Keri RA 2011 Bisphenol A increases mammary cancer risk in two distinct mouse models of breast cancer. Biology of Reproduction 85 490-497. (doi:10.1095/biolreprod.110.090431)

Weng YI, Hsu PY, Liyanarachchi S, Liu J, Deatherage DE, Huang YW, Zuo T, Rodriguez B, Lin CH, Cheng AL et al. 2010 Epigenetic influences of low-dose bisphenol A in primary human breast epithelial cells. Toxicology and Applied Pharmacology 248 111-121. (doi:10.1016/j.taap. 2010.07.014)

White SS, Calafat AM, Kuklenyik Z, Villanueva L, Zehr RD, Helfant L, Strynar MJ, Lindstrom AB, Thibodeaux JR, Wood C et al. 2007 Gestational PFOA exposure of mice is associated with altered mammary gland development in dams and female offspring. Toxicological Sciences 96 133-144. (doi:10.1093/toxsci/kfl177)

White SS, Kato K, Jia LT, Basden BJ, Calafat AM, Hines EP, Stanko JP, Wolf CJ, Abbott BD \& Fenton SE 2009 Effects of perfluorooctanoic acid on mouse mammary gland development and differentiation resulting from cross-foster and restricted gestational exposures. Reproductive Toxicology 27 289-298. (doi:10.1016/j.reprotox.2008.11.054)

White SS, Fenton SE \& Hines EP 2011 $a$ Endocrine disrupting properties of perfluorooctanoic acid. Journal of Steroid Biochemistry and Molecular Biology 127 16-26. (doi:10.1016/j.jsbmb.2011.03.011)

White SS, Stanko JP, Kato K, Calafat AM, Hines EP \& Fenton SE $2011 b$ Gestational and chronic low-dose PFOA exposures and mammary gland growth and differentiation in three generations of CD-1 mice. Environmental Health Perspectives 119 1070-1076. (doi:10.1289/ehp. 1002741)

Wild CP 2005 Complementing the genome with an "exposome": the outstanding challenge of environmental exposure measurement in molecular epidemiology. Cancer Epidemiology, Biomarkers \& Prevention 14 1847-1850. (doi:10.1158/1055-9965.EPI-05-0456)

Wilson VL \& Jones PA 1983 Inhibition of DNA methylation by chemical carcinogens in vitro. Cell 32 239-246. (doi:10.1016/00928674(83)90514-7)

Wojtowicz AK, Goch M \& Gregoraszczuk EL 2005 Polychlorinated biphenyls (PCB 153 and PCB 126) action on conversion of 20-hydroxylated cholesterol to progesterone, androstenedione to testosterone, and testosterone to estradiol $17 \beta$. Experimental and Clinical Endocrinology \& Diabetes 113 464-470. (doi:10.1055/s-2005-865776)

Wolff MS, Toniolo PG, Lee EW, Rivera M \& Dubin N 1993 Blood levels of organochlorine residues and risk of breast cancer. Journal of the National Cancer Institute 85 648-652. (doi:10.1093/jnci/85.8.648)

Wu Q, Ohsako S, Ishimura R, Suzuki JS \& Tohyama C 2004 Exposure of mouse preimplantation embryos to 2,3,7,8-tetrachlorodibenzop-dioxin (TCDD) alters the methylation status of imprinted genes $H 19$ and Igf2. Biology of Reproduction 70 1790-1797. (doi:10.1095/biolreprod.103.025387)

Xu L, Xiang J, Shen J, Zou X, Zhai S, Yin Y, Li P, Wang X \& Sun Q 2004 Oncogenic microRNA-27a is a target for genistein in ovarian cancer cells. Anti-Cancer Agents in Medicinal Chemistry 13 1126-1132. (doi:10.2174/18715206113139990006)

You JS \& Jones PA 2012 Cancer genetics and epigenetics: two sides of the same coin? Cancer Cell 22 9-20. (doi:10.1016/j.ccr.2012.06.008)

Zentner GE \& Henikoff S 2013 Regulation of nucleosome dynamics by histone modifications. Nature Structural \& Molecular Biology 20 259-266. (doi:10.1038/nsmb.2470)

Zhao Y, Tan YS, Haslam SZ \& Yang C 2010 Perfluorooctanoic acid effects on steroid hormone and growth factor levels mediate stimulation of peripubertal mammary gland development in C57BL/6 mice. Toxicological Sciences 115 214-224. (doi:10.1093/toxsci/kfq030)

Zheng T, Holford TR, Mayne ST, Tessari J, Ward B, Carter D, Owens PH, Boyle P, Dubrow R, Archibeque-Engle S et al. 2000 Risk of female breast cancer associated with serum polychlorinated biphenyls and 1,1-dichloro-2,2'-bis( $p$-chlorophenyl)ethylene. Cancer Epidemiology, Biomarkers \& Prevention 9 167-174.

Zhong S, Tang MW, Yeo W, Liu C, Lo YM \& Johnson PJ 2002 Silencing of GSTP1 gene by CpG island DNA hypermethylation in HBV-associated hepatocellular carcinomas. Clinical Cancer Research 8 1087-1092.

Received in final form 3 February 2014

Accepted 5 February 2014

Made available online as an Accepted Preprint

14 February 2014 http://erc.endocrinology-journals.org DOI: 10.1530/ERC-13-0513
(C) 2014 Society for Endocrinology Printed in Great Britain
Published by Bioscientifica Ltd. 